\title{
Ecology, evolution, and the long-term surveillance of vector-borne Chagas disease: A multi-scale appraisal of the tribe Rhodniini (Triatominae)
}

\author{
Fernando Abad-Franch ${ }^{\mathrm{a}, *}$, Fernando A. Monteiro ${ }^{\mathrm{b}}$, Nicolás Jaramillo O.c, \\ Rodrigo Gurgel-Gonçalves ${ }^{\mathrm{d}, \mathrm{e}}$, Fernando Braga Stehling Dias ${ }^{\mathrm{f}}$, Liléia Diotaiuti ${ }^{\mathrm{f}}$ \\ a Instituto Leônidas e Maria Deane - Fiocruz Amazônia, Rua Teresina 476, CEP 69057-070 Manaus, Amazonas, Brazil \\ ${ }^{\mathrm{b}}$ Departamento de Medicina Tropical, Instituto Oswaldo Cruz - Fiocruz, Av. Brasil 4365, CEP 21045-900 Rio de Janeiro, RJ, Brazil \\ c Instituto de Biología, Universidad de Antioquia. Sede de Investigaciones Universitarias - SIU, Calle 62, no. 52-59, Medellín, Colombia \\ ${ }^{\mathrm{d}}$ Laboratório de Parasitologia Médica e Biologia de Vetores, Faculdade de Medicina, Área de Patologia, Universidade de Brasília, Asa Norte, \\ CEP 70.910-900 Brasília, DF, Brazil \\ e Laboratório de Zoologia, Universidade Católica de Brasília, QS 07 Lote 01 EPTC Bloco M, sala 331, CEP 72030-170 Brasília, DF, Brazil \\ ${ }^{\mathrm{f}}$ Laboratório de Triatomíneos e Epidemiologia da Doença de Chagas, Centro de Pesquisas René Rachou - Fiocruz, Av. Augusto de Lima 1715, \\ CEP 30190-002 Belo Horizonte, Minas Gerais, Brazil
}

\section{A R T I C L E I N F O}

\section{Article history:}

Available online 21 June 2008

\section{Keywords:}

Rhodniini

Triatominae

Rhodnius neglectus

Rhodnius nasutus

Biogeography

Ecology

Species richness

Species composition

Evolution

Chagas disease surveillance

\begin{abstract}
A B S T R A C T
Chagas disease incidence has sharply declined over the last decade. Long-term disease control will, however, require extensive, longitudinal surveillance systems capable of detecting (and dealing with) reinvasion-reinfestation of insecticide-treated dwellings by non-domiciliated triatomines. Sound surveillance design calls for reliable data on vector ecology, and these data must cover different spatial scales. We conducted a multi-scale assessment of ecological and evolutionary trends in members of the tribe Rhodniini, including (i) a macroscale analysis of Rhodniini species richness and composition patterns across the Americas, and (ii) a detailed, mesoscale case-study of ecological and behavioural trends in Rhodnius neglectus and $R$. nasutus. Our macroscale overview provides some comprehensive insights about key mechanisms/processes probably underlying ecological and genetic diversification in the Rhodniini. These insights translate into a series of testable hypotheses about current species distributions and their likely causes. At the landscape scale, we used geometric morphometrics to identify dubious specimens as either R. neglectus or R. nasutus (two near-sibling species), and studied palm tree populations of these two vector taxa in five geographical areas. The data suggest that deforestation and the associated loss of habitat and host diversity might increase the frequency of vector-human contact (and perhaps Trypanosoma cruzi infection rates in vectors). Surveillance in central-northeastern Brazil should prioritise deforested landscapes where large palm trees (e.g., Attalea, Mauritia, Copernicia, Acrocomia or Syagrus) occur near houses. We anticipate that, by helping define the distribution patterns and ecological preferences of each species, multi-scale research will significantly strengthen vector surveillance systems across Latin America.
\end{abstract}

(c) 2008 Elsevier B.V. All rights reserved.
Chagas disease is caused by Trypanosoma cruzi (Kinetoplastida: Trypanosomatidae), a parasite transmitted by blood-sucking reduviid bugs (Triatominae) (Chagas, 1909; Coura, 2007). Human infection is endemic throughout Latin America, where its associated burden is larger than the combined burden of malaria, leprosy, leishmaniasis, filariasis, schistosomiasis, dengue, and the major intestinal nematode infections (WHO, 2004; Mathers et al., 2006). In the last 10-15 years, T. cruzi transmission to people has nonetheless been interrupted over vast areas of southern South America, with an estimated $73 \%$ reduction in incidence and sharp declines

\footnotetext{
* Corresponding author. Tel.: +55 92 36212401/36212323; fax: +55 9236212363.

E-mail address: fernando@amazonia.fiocruz.br (F. Abad-Franch).
}

in burden figures (World Bank, 1993; Morel and Lazdins, 2003; Mathers et al., 2006). These successful control programmes prioritised elimination of domestic triatomines (through the spraying of households with residual insecticides) and systematic serological screening of blood donations (Anonymous, 2007).

One major hindrance for the long-term consolidation of effective disease control is the widespread occurrence of native triatomine species that reinvade and sporadically reinfest insecticide-treated households (Miles et al., 2003; Coura, 2007). Both ecological and evolutionary factors are involved in these dispersion-colonisation dynamics, but their relative roles remain poorly understood (AbadFranch and Monteiro, 2007).

In this paper we suggest that the complex interactions involved in sustained T. cruzi transmission by sylvatic triatomines are hierar- 
chically structured in space, and that considering different spatial scales may, therefore, significantly improve our ability to understand these transmission dynamics. Following this rationale, we present a multi-scale appraisal of ecological and evolutionary trends in a monophyletic group of triatomines, the tribe Rhodniini. This tribe encompasses species displaying different degrees of synanthropic behaviour, from primary domestic vectors to strictly sylvatic taxa. In the first part we present a macroscale (continental) analysis of Rhodniini diversity patterns across the Americas. The second part presents a detailed, mesoscale (ecoregional) casestudy of ecological and behavioural trends in two secondary vectors of Chagas disease, the near-sibling $R$. neglectus and $R$. nasutus. Systematic, biogeographical, and ecological issues are discussed throughout the text. We argue that this multi-scale approach may substantially strengthen vector surveillance by helping allocate resources to priority areas; in more academic terms, it may at the same time prove crucial in fostering the emergence of a coherent account of the evolution and behavioural trends of the Triatominae.

\section{Macroscale biogeographical patterns and ecology of the members of the tribe Rhodniini}

\subsection{Introduction}

Species richness (the number of types in a given community or geographical region, or alpha-diversity) is a major component of biological diversity estimates (Gotelli and Colwell, 2001; Mittermeier et al., 2003). Information on the presence/absence of species (or other taxonomic units within a given lineage) over a set of different ecological regions may also be used, in combination with phylogenetic reconstructions, to derive and contrast biogeographical and evolutionary hypotheses regarding that lineage (e.g., Ribas et al., 2005; Conn and Mirabello, 2007). Conversely, species distribution data can provide insights on the patterns of current ecological relatedness among geographical areas (e.g., Ron, 2000; Porzecanski and Cracraft, 2005).

When the focus of research is a lineage of human disease vectors, the study of ecological and (current or historical) biogeographical patterns is not only of academic interest. For instance, it may also help define the potential geographical ranges of species that are more efficient vectors (or of the clades containing those species), and this information can in turn be used to stratify disease transmission risk in spatially explicit analytical frameworks (Ostfeld et al., 2005). Biogeographical-evolutionary analyses can also provide clues as to the evolution of disease vector traits (such as synanthropism, or the capacity of successfully adapting to breed in man-made ecotopes) that are spatially correlated with epidemiological indicators (such as disease prevalence in humans). In the case of triatomine bugs, the combination of long-lasting field research and novel analytical tools is opening research avenues that may lead to improved chances of effectively controlling Chagas disease transmission in the long term (Monteiro et al., 2001; Miles et al., 2003; Abad-Franch and Monteiro, 2005). One particularly difficult challenge to this goal is the persistent reinvasion and (more rarely) reinfestation of insecticide-treated households by sylvatic triatomines; understanding the ecological and evolutionary dynamics involved in these events may prove crucial for the design of adequate vector surveillance strategies, and the contribution of broad-scale biogeographical insights can be key to such efforts (Forattini, 1980; Miles et al., 2003; Schofield et al., 2006; Abad-Franch and Monteiro, 2007; de Paula et al., 2007).

The Rhodniini constitute a particularly interesting case-study lineage for biogeographical research. They are a monophyletic assemblage of 19 named species within two genera (the monophyletic Psammolestes [three species] and the paraphyletic Rhodnius [16 species]) that occur naturally in 25-27 biogeographical provinces (sensu Morrone, 2006) in the Neotropical Region (Abad-Franch and Monteiro, 2007). They are arboricolous (treeliving), blood-sucking true bugs, most of them primarily associated with palm tree crown habitats. A few taxa occur in ecotopes other than palms; for instance, the three known Psammolestes species seem to have specialised to exploit bird nest microhabitats in open woodlands (Lent and Wygodzinsky, 1979). R. prolixus, the main vector of human Chagas disease in Central and northern South America (and probably worldwide after the elimination of domestic Triatoma infestans populations from large areas of South America), belongs to this tribe. Another moderately important, synanthropic vector is $R$. ecuadoriensis, and four species (R. pallescens, $R$. neglectus, $R$. nasutus, and $R$. stali) invade and sporadically colonise human environments. In Amazonia, palm tree populations of $R$. robustus sensu lato, $R$. pictipes, and $R$. brethesi act as sources of adult adventitious bugs that invade (but do not colonise) houses, contaminate food-processing equipment, or attack forest workers (cf. Coura et al., 2002; Aguilar et al., 2007). Other species within the tribe seem to have little or no contact with humans (Barrett, 1991).

Here we present a broad-scale analysis of biogeographical patterns among members of the tribe Rhodniini across continental Latin America. Our (mostly descriptive) survey explores spatial trends of regional difference/similarity in terms of Rhodniini species richness and composition both for individual ecoregions and for larger ecoregion clusters matching previously postulated areas of endemicity. The results, which are to be regarded as informed biogeographical hypotheses, are discussed in relation to the ecology of individual species and species groups and to the evolutionary history of each lineage.

\subsection{Materials and methods}

Presence records were compiled (and refined) from the literature (mainly Carcavallo et al., 1999 and Galvão et al., 2003, with newer data from Colombia [Guhl et al., 2007], Peru [Chávez, 2006], Central America [Zeledón et al., 2006], and Amazonia [Abad-Franch and Monteiro, 2007]), and from our field research activities, for each species within the tribe Rhodniini. Well-characterised mitochondrial lineages were treated as distinct entities whenever enough data were available. Following operational guidelines derived from DNA barcoding (e.g., Hebert et al., 2003a,b, 2004; Miller, 2007; Ratnasingham and Hebert, 2007), any mitochondrial cytochrome $b$ (cyt $b$ ) gene monophyletic lineage that differed by over 0.02 Kimura 2-parameter distance from its sister lineage was treated as a distinct operational taxonomic unit (OTU) (cf. Blaxter et al., 2005; see also Avise and Walker, 1999; Pons et al., 2006). Thus, R. robustus was treated as a complex of five OTUs (I-V) (Monteiro et al., 2003; AbadFranch and Monteiro, 2007; Pavan and Monteiro, 2007), and $R$. ecuadoriensis was divided into two groups (I and II) (Abad-Franch et al., 2004). A novel, highly divergent cytb genotype recently isolated from bugs resembling $R$. pictipes and collected in the Colombian Sierra Nevada de Santa Marta (NJO and FAM, unpublished) was also treated as distinct (Rhodnius n.sp. aff. pictipes). An apparently new species from northwestern Amazonia (basal to the robustus species group), detected by DNA barcoding (Abad-Franch and Monteiro, 2005), was also considered as a separate entity (Rhodnius n.sp. aff. robustus). Recent data suggest that a similar treatment is valid for two well-differentiated $R$. pallescens lineages (I and II) (NJO and FAM, unpublished). Thus, a total number of 27 OTUs was incorporated into our survey (Table 1 ).

We defined the distribution patterns of each OTU across the continental ecoregions of Latin America proposed by the World Wildlife Foundation (WWF-TNC, 2001; see also Olson et al., 2001). 
Table 1

Biogeographical patterns of 27 species/taxonomic units within the tribe Rhodniini: presence/absence records across 68 Neotropical ecoregions and 11 areas of endemism.

\begin{tabular}{|c|c|c|c|c|c|c|c|c|c|c|c|c|c|c|c|c|c|c|c|c|c|c|c|c|c|c|c|c|c|c|}
\hline \multirow{2}{*}{ Area } & \multirow{2}{*}{ MN } & \multirow{2}{*}{ Ecoregion } & \multicolumn{27}{|c|}{ Operational Taxonomic Units } & \\
\hline & & & 1 & 2 & 3 & 4 & 5 & 6 & 7 & 8 & 9 & 10 & 11 & 12 & 13 & 14 & 15 & 16 & 17 & 18 & 19 & 20 & 21 & 22 & 23 & 24 & 25 & 26 & 27 & \\
\hline \multirow[t]{15}{*}{ Trans-Andean } & - & Central American Atlantic m.f. & & & & & & & & & & & & & & & & & & & & & & & & & & & & 1 \\
\hline & - & Isthmian-Pacific m.f. & & & & & & & & & & & & & & & & & & & & & & & & & & & & 1 \\
\hline & - & Chocó/Darién m.f. & & & & & & & & & & & & & & & & & & & & & & & & & & & & 1 \\
\hline & - & Magdalena/Urabá m.f. & & & & & & & & & & & & & & & & & & & & & & & & & & & & 2 \\
\hline & 1 & Guajira/Barranquilla x.sc. & & & & & & & & & & & & & & & & & & & & & & & & & & & & 3 \\
\hline & 2 & Santa Marta mn.f. & & & & & & & & & & & & & & & & & & & & & & & & & & & & 3 \\
\hline & - & Sinú Valley d.f. & & & & & & & & & & & & & & & & & & & & & & & & & & & & 2 \\
\hline & - & Cordillera Oriental mn.f. (T-A side) & & & & & & & & & & & & & & & & & & & & & & & & & & & & 2 \\
\hline & - & Magdalena Valley mn.f. & & & & & & & & & & & & & & & & & & & & & & & & & & & & 2 \\
\hline & - & Magdalena Valley d.f. & & & & & & & & & & & & & & & & & & & & & & & & & & & & 2 \\
\hline & - & Northwestern Andean mn.f. & & & & & & & & & & & & & & & & & & & & & & & & & & & & 1 \\
\hline & - & Western Ecuador m.f. & & & & & & & & & & & & & & & & & & & & & & & & & & & & 1 \\
\hline & - & Ecuadorian d.f. & & & & & & & & & & & & & & & & & & & & & & & & & & & & 1 \\
\hline & - & Tumbes/Piura d.f. & & & & & & & & & & & & & & & & & & & & & & & & & & & & 2 \\
\hline & - & Central Andean wet puna & & & & & & & & & & & & & & & & & & & & & & & & & & & & 1 \\
\hline \multirow[t]{10}{*}{ Orinoco } & 3 & Paraguaná X.sc. & & & & & & & & & & & & & & & & & & & & & & & & & & & & 5 \\
\hline & 4 & Maracaibo d.f. & & & & & & & & & & & & & & & & & & & & & & & & & & & & 5 \\
\hline & 5 & Lara/Falcón d.f. & & & & & & & & & & & & & & & & & & & & & & & & & & & & 5 \\
\hline & 6 & La Costa X.s. & & & & & & & & & & & & & & & & & & & & & & & & & & & & 4 \\
\hline & 7 & Catatumbo m.f. & & & & & & & & & & & & & & & & & & & & & & & & & & & & 3 \\
\hline & 8 & Venezuelan Andes mn.f. & & & & & & & & & & & & & & & & & & & & & & & & & & & & 3 \\
\hline & 9 & Apure/Villavicencio d.f. & & & & & & & & & & & & & & & & & & & & & & & & & & & & 6 \\
\hline & 10 & Orinoco Delta swamps and wetlands & & & & & & & & & & & & & & & & & & & & & & & & & & & & 4 \\
\hline & 11 & Llanos & & & & & & & & & & & & & & & & & & & & & & & & & & & & 5 \\
\hline & 12 & Cordillera Oriental mn.f. (Or side) & & & & & & & & & & & & & & & & & & & & & & & & & & & & 6 \\
\hline
\end{tabular}


Table 1 (Continued)

\begin{tabular}{|c|c|c|c|c|c|c|c|c|c|c|c|c|c|c|c|c|c|c|c|c|c|c|c|c|c|c|c|c|c|c|}
\hline \multirow{2}{*}{ Area } & \multirow{2}{*}{ MN } & \multirow{2}{*}{ Ecoregion } & \multicolumn{27}{|c|}{ Operational Taxonomic Units } & \multirow{2}{*}{$\mathbf{N}$} \\
\hline & & & 1 & 2 & 3 & 4 & 5 & 6 & 7 & 8 & 9 & 10 & 11 & 12 & 13 & 14 & 15 & 16 & 17 & 18 & 19 & 20 & 21 & 22 & 23 & 24 & 25 & 26 & 27 & \\
\hline \multirow[t]{7}{*}{ Guyanan } & 13 & Guyanan Highlands m.f. & & & & & & & & & & & & & & & & & & & & & & & & & & & & 4 \\
\hline & 14 & Guianan m.f. and Paramaribo sw.f. & & & & & & & & & & & & & & & & & & & & & & & & & & & & 5 \\
\hline & 15 & Negro/Branco m.f. & & & & & & & & & & & & & & & & & & & & & & & & & & & & 6 \\
\hline & 16 & Guyanan savannahs & & & & & & & & & & & & & & & & & & & & & & & & & & & & 3 \\
\hline & 17 & Rio Negro campinaranas & & & & & & & & & & & & & & & & & & & & & & & & & & & & 4 \\
\hline & 18 & Uatumã-Trombetas m.f. & & & & & & & & & & & & & & & & & & & & & & & & & & & & 5 \\
\hline & 19 & Marajó and Gurupa várzeas & & & & & & & & & & & & & & & & & & & & & & & & & & & & 4 \\
\hline \multirow[t]{4}{*}{ Napo } & 20 & Caquetá m.f. & & & & & & & & & & & & & & & & & & & & & & & & & & & & 4 \\
\hline & 21 & Eastern Cordillera Real mn.f. & & & & & & & & & & & & & & & & & & & & & & & & & & & & 3 \\
\hline & 22 & Napo m.f. & & & & & & & & & & & & & & & & & & & & & & & & & & & & 5 \\
\hline & 23 & Solimões/Japurá m.f. & & & & & & & & & & & & & & & & & & & & & & & & & & & & 4 \\
\hline Imerí & 24 & Japurá/Solimões-Negro m.f. & & & & & & & & & & & & & & & & & & & & & & & & & & & & 5 \\
\hline \multirow[t]{10}{*}{ Inambari } & 25 & Monte Alegre várzea & & & & & & & & & & & & & & & & & & & & & & & & & & & & 4 \\
\hline & 26 & Purus várzea & & & & & & & & & & & & & & & & & & & & & & & & & & & & 4 \\
\hline & - & Iquitos várzea & & & & & & & & & & & & & & & & & & & & & & & & & & & & 2 \\
\hline & 27 & Juruá/Purus m.f. & & & & & & & & & & & & & & & & & & & & & & & & & & & & 3 \\
\hline & 28 & Purus/Madeira m.f. & & & & & & & & & & & & & & & & & & & & & & & & & & & & 3 \\
\hline & - & Peruvian yungas & & & & & & & & & & & & & & & & & & & & & & & & & & & & 2 \\
\hline & - & Ucayali m.f. & & & & & & & & & & & & & & & & & & & & & & & & & & & & 2 \\
\hline & 29 & Southwestern Amazonian m.f. & & & & & & & & & & & & & & & & & & & & & & & & & & & & 5 \\
\hline & 30 & Beni savannahs & & & & & & & & & & & & & & & & & & & & & & & & & & & & 3 \\
\hline & - & Bolivian yungas & & & & & & & & & & & & & & & & & & & & & & & & & & & & 2 \\
\hline
\end{tabular}




\begin{tabular}{|c|c|c|c|c|c|c|c|c|c|c|c|c|c|c|c|c|c|c|c|c|c|c|c|c|c|c|c|c|c|c|}
\hline \multirow{2}{*}{ Area } & \multirow{2}{*}{ MN } & \multirow{2}{*}{ Ecoregion } & \multicolumn{27}{|c|}{ Operational Taxonomic Units } & \multirow{2}{*}{$\mathbf{N}$} \\
\hline & & & 1 & 2 & 3 & 4 & 5 & 6 & 7 & 8 & 9 & 10 & 11 & 12 & 13 & 14 & 15 & 16 & 17 & 18 & 19 & 20 & 21 & 22 & 23 & 24 & 25 & 26 & 27 & \\
\hline Rondônia & 31 & Madeira/Tapajós m.f. & & & & & & & & & & & & & & & & & & & & & & & & & & & & 6 \\
\hline \multirow[t]{3}{*}{ Pará } & 32 & Tapajós/Xingu m.f. & & & & & & & & & & & & & & & & & & & & & & & & & & & & 5 \\
\hline & 33 & Xingu/Tocantins-Araguaia m.f. & & & & & & & & & & & & & & & & & & & & & & & & & & & & 6 \\
\hline & 34 & Mato Grosso tropical d.f. & & & & & & & & & & & & & & & & & & & & & & & & & & & & 5 \\
\hline \multirow[t]{2}{*}{ Belém } & 35 & Tocantins-Araguaia/Maranhão m.f. & & & & & & & & & & & & & & & & & & & & & & & & & & & & 8 \\
\hline & 36 & Maranhão babaçu forests & & & & & & & & & & & & & & & & & & & & & & & & & & & & 7 \\
\hline \multirow[t]{8}{*}{ Open/Dry Corridor } & 37 & Caatinga & & & & & & & & & & & & & & & & & & & & & & & & & & & & 3 \\
\hline & 38 & Northeast Brazil d.f. & & & & & & & & & & & & & & & & & & & & & & & & & & & & 3 \\
\hline & 39 & Cerrado & & & & & & & & & & & & & & & & & & & & & & & & & & & & 6 \\
\hline & 40 & Chiquitania d.f. & & & & & & & & & & & & & & & & & & & & & & & & & & & & 4 \\
\hline & 41 & Pantanal & & & & & & & & & & & & & & & & & & & & & & & & & & & & 5 \\
\hline & - & Bolivian montane d.f. & & & & & & & & & & & & & & & & & & & & & & & & & & & & 1 \\
\hline & - & Chaco savannahs & & & & & & & & & & & & & & & & & & & & & & & & & & & & 2 \\
\hline & - & Andean yungas & & & & & & & & & & & & & & & & & & & & & & & & & & & & 1 \\
\hline \multirow{8}{*}{$\begin{array}{l}\text { Atlantic/Humid } \\
\text { Corridor }\end{array}$} & - & Pernambuco c. and i.f. & & & & & & & & & & & & & & & & & & & & & & & & & & & & 1 \\
\hline & - & Bahia i.f. & & & & & & & & & & & & & & & & & & & & & & & & & & & & 2 \\
\hline & - & Bahia c.f. & & & & & & & & & & & & & & & & & & & & & & & & & & & & 1 \\
\hline & - & Humid Chaco & & & & & & & & & & & & & & & & & & & & & & & & & & & & 1 \\
\hline & 42 & Paraná/Paraíba i.f. & & & & & & & & & & & & & & & & & & & & & & & & & & & & 3 \\
\hline & - & Brazilian Araucaria m.f. & & & & & & & & & & & & & & & & & & & & & & & & & & & & 1 \\
\hline & - & Serra do Mar c.f. & & & & & & & & & & & & & & & & & & & & & & & & & & & & 1 \\
\hline & - & Mesopotamian savannahs & & & & & & & & & & & & & & & & & & & & & & & & & & & & 1 \\
\hline Total & & & 4 & 7 & 1 & 2 & 4 & 2 & 8 & 14 & 6 & 13 & 37 & 12 & 5 & 16 & 2 & 6 & 3 & 5 & 2 & 22 & 7 & 3 & 11 & 8 & 12 & 9 & 5 & \\
\hline
\end{tabular}

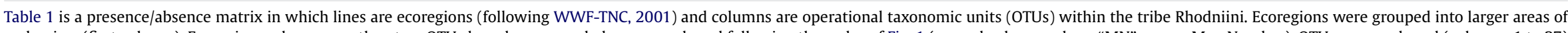

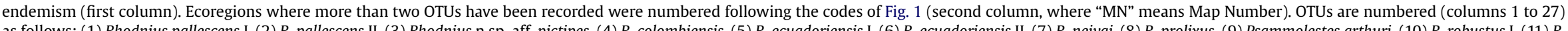

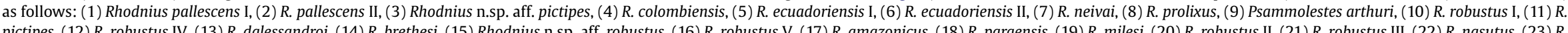
pictipes, (12) R. robustus IV, (13) R. dalessandroi, (14) R. brethesi, (15) Rhodnius n.sp. aff. robustus, (16) R. robustus V, (17) R. amazonicus, (18) R. paraensis, (19) R. milesi, (20) R. robustus II, (21) R. robustus III, (22) R. nasutus, (23) R.

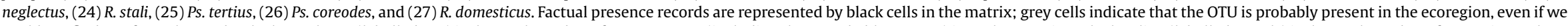

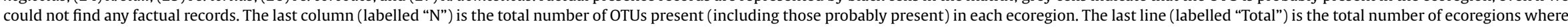
could

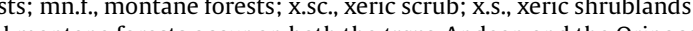

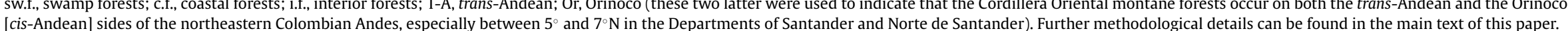


Presence records were not available for several OTUs over their whole probable range. We overcame this limitation by deriving "probable presence" through interpolation (and in a few cases extrapolation) of factual records across contiguous ecoregions with similar overall ecological characteristics. This procedure was relatively straightforward in most instances but problematic in a few; the main adverse effect of these latter cases would be an unwarranted increase in similarity between areas because of spurious OTU sharing. In this sense, some of the results we present here must be viewed as proximal biogeographical hypotheses to be confirmed or rejected by further field data.

Raw OTU counts from each ecoregion were plotted onto a vegetation/elevation map of Latin America (TNC, 2001) to graphically display richness patterns (Fig. 1).
Ecoregions were grouped into eleven major clusters for Parsimony Analysis of Endemicity (PAE) (Rosen, 1988; Rosen and Smith, 1988) and phenetic analyses (e.g., Condit et al., 2002). Ecoregion groupings (Table 1) largely followed Haffer's (1969) centres of endemism for Amazonian lowland forests, which were used to derive the Refuge hypothesis of biotic diversification (Haffer, 1969, 1997). Ecoregions south of Amazonia were grouped into two clusters: the Open/dry and the Atlantic/humid corridors (see Porzecanski and Cracraft, 2005); finally, all trans-Andean ecoregions were treated as a single area. PAE is a procedure equivalent to phylogenetic cladistic analysis in which localities/areas are treated as taxa and OTUs as two-state (presence/absence) characters (e.g., Ron, 2000; Racheli and Racheli, 2004; Garzón-Orduña et al., 2007). Cladistic analysis of Rhodniini OTU presence/absence patterns was

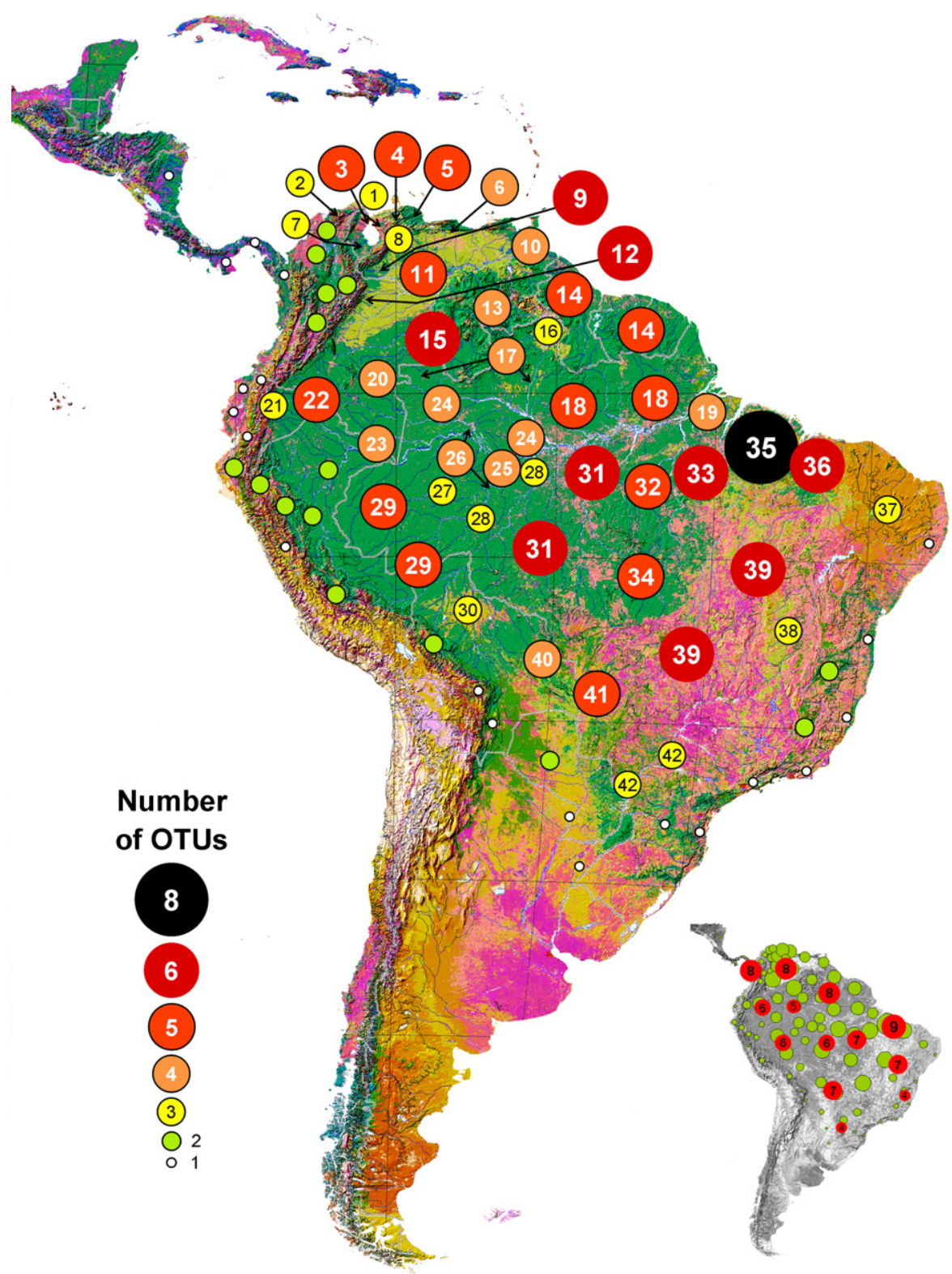

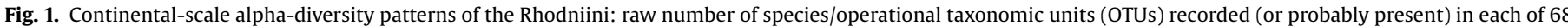

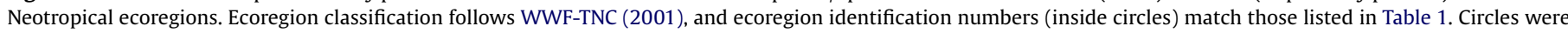

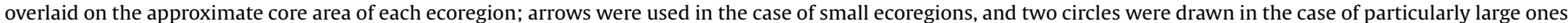

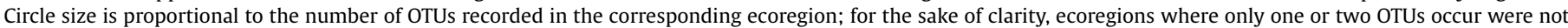

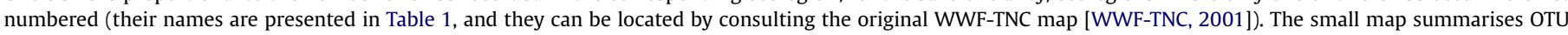
richness by area of endemicity (as defined in Fig. 2). 
thus performed on an 11-area, 27-taxon matrix. We used standard maximum parsimony with a branch-and-bound search algorithm as implemented in Mega 3.1 (Kumar et al., 2004). Singletons in this kind of data matrix are species endemic to single regions (narrow endemics), while parsimony-informative "sites" are OTUs shared by two or more regions. Trees were rooted with a hypothetical all-absence outgroup region. Additionally, we calculated pairwise dissimilarity matrices among areas based on the Jaccard's and Sørensen's measures of the fraction of shared species (cf. Condit et al., 2002), and used them as input to derive cladograms using the Unweighted Pair Group Method with Arithmetic Mean (UPGMA). Jaccard's dissimilarity index is given by $D J=1-\left[S_{12} /\left(S_{1}+S_{2}-S_{12}\right)\right]$, and Sørensen's index by DS $=1-\left[\mathrm{S}_{12} /\left(0.5\left[\mathrm{~S}_{1}+\mathrm{S}_{2}\right]\right)\right]$; in both cases, $S_{12}$ is the number of species shared by areas 1 and $2, S_{1}$ is the total number of species in area 1 , and $S_{2}$ is the total number of species in area 2.

\subsection{Results and discussion}

\subsubsection{Patterns of OTU richness}

The Rhodniini occur naturally from Central America (approx. $15^{\circ} \mathrm{N}$ ) to northern Argentina (approx. $33^{\circ} \mathrm{S}$ ). This tribe probably conceals more alpha-systematic diversity than described by the 19 species hitherto recognised (Galvão et al., 2003). We found phylogenetic evidence to define eight further taxonomic units for our biogeographical survey (Abad-Franch et al., 2003a,b; AbadFranch and Monteiro, 2005, 2007; Monteiro et al., 2003; Pavan and Monteiro, 2007; FA-F, NJO and FAM, unpublished data). Some of these new taxonomic units indubitably deserve specific status, while others are relatively young monophyletic lineages that may be hypothesised to represent 'good species' or, for the purposes of our study, 'good OTUs' (see Hebert et al., 2003a,b; Blaxter et al., 2005; Pons et al., 2006; Ratnasingham and Hebert, 2007).
Overall, these 27 Rhodniini OTUs have been recorded to occur in 68 ecoregions-from the Central American Atlantic moist forests to the Mesopotamian savannahs of northeastern Argentina, and from very humid (e.g., the Napo moist forests) to very arid (e.g., the Peruvian coastal dry forests) ecoregions (Figs. 1 and 2). Visual inspection of Fig. 1 suggests that species (OTU) richness is higher in Amazonia (particularly in southeastern ecoregions) and in the two drier biomes adjacent to Amazonia to the north (the greater Orinoco) and to the south (the Cerrado). The main richness "hotspot" corresponds to the Tocantins-Araguaia/Maranhão moist forests, from where six OTUs have been recorded and where two more are likely to occur. The Belém area of endemicity, which encompasses this ecoregion and the Maranhão babaçu forests (dominated by Attalea speciosa palm trees), probably harbours at least nine Rhodniini OTUs (Table 1). OTU numbers per ecoregion decrease substantially beyond the boundaries of the Orinoco-Amazonia-Cerrado area. There are also signals of heterogeneity within Amazonia, where a cluster of relatively species-poor ecoregions (numbers 17, 20 and 23-28 plus four ecoregions in the Peruvian Amazon) appears in the central/central-western subregion (Fig. 1). These ecoregions are related to several large rivers (Branco, Negro, lower Napo, upper Solimões-Marañón, Juruá, Purus, the left bank of the Madeira, and parts of the Amazon itself) and to extensive flooded forest regions within white-water systems (the várzea).

When sorted according to latitude, the distribution of OTU numbers across areas of endemicity is bimodal, with lower values corresponding to (a) central/central-western Amazonia (Imerí, Inambari and Rondônia) and (b) the southeastern Atlantic/humid corridor, with one narrow endemic and three OTUs shared with the open/dry corridor (Fig. 2).

One interpretation of these patterns could be that richer areas (the Orinoco basin, southeastern Amazonia, and the Cerrado) cor-

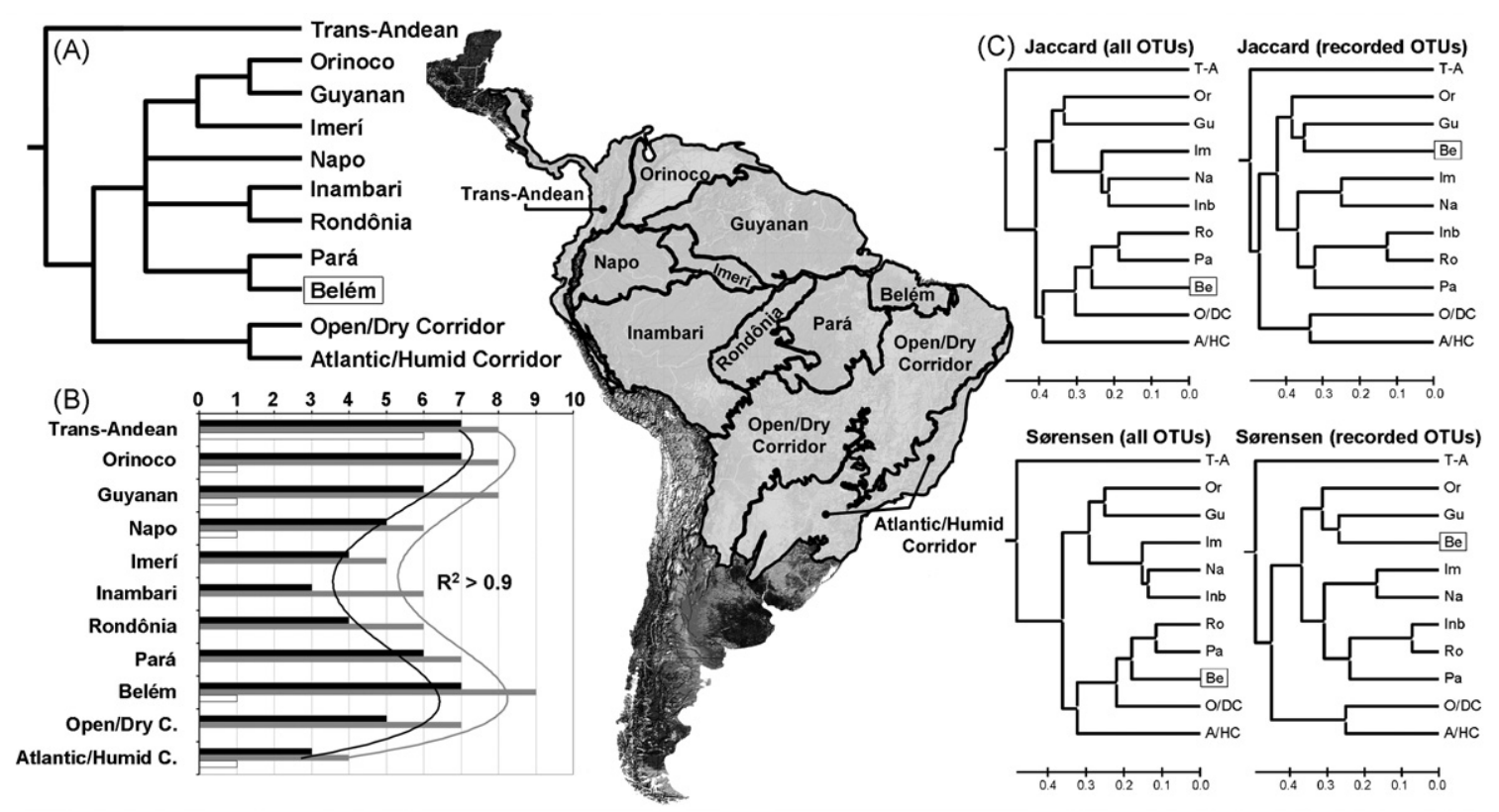

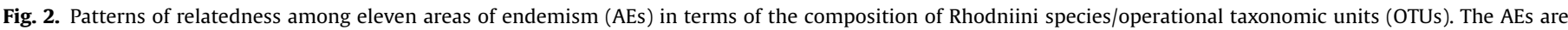

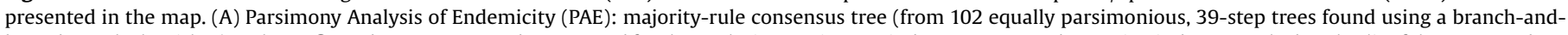

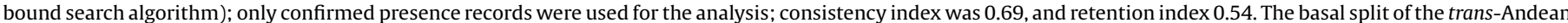

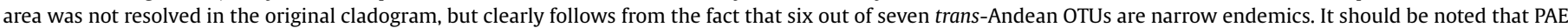

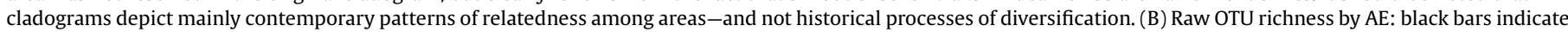

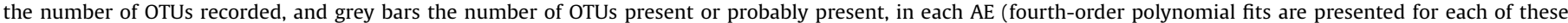

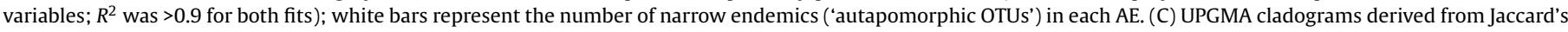

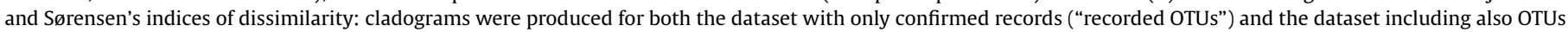
probably present in each area ("all OTUs"). The unstable position of the Belém area of endemicity (the main OTU richness "hotspot") is highlighted by a box. 
respond to the centres of endemism where the parental lineages of extant OTUs diversified. This interpretation derives from the view that higher current diversity signals more dynamic past diversification, and that later events (emigration, immigration, and extinction) did not overwhelm that signal. Also plausible is the idea that at least some of these OTU rich-areas are contact zones where representatives of formerly allopatric or parapatric lineages live now in sympatry.

This latter view seems compatible with the observation that rich ecoregions (those with $\geq 6$ OTUs) tend to share boundaries with areas of endemism other than the one they belong to; two apparent exceptions (out of seven) correspond to border ecoregions between Andean montane and lowland dry forests within the Orinoco system. All these "hotspot" ecoregions tend to contain OTUs that most likely evolved elsewhere and secondarily colonised them through dispersal (see below).

Under this scenario, the pattern of relatively low OTU richness in a cluster of central-western Amazonian ecoregions could be interpreted as the "null pattern" for large, relatively homogeneous ecoregion clusters. Extensive annual white-water floods across this subregion may also affect Rhodniini diversity by limiting the local diversity of large palms; thus, several Attalea, Oenocarpus, Syagrus, and (to a lesser extent) Astrocaryum species occur mainly in upland forests on well-drained soils and may be absent or rare in the várzea (Kahn, 1990). Finally, and perhaps most interestingly, this lowrichness subregion visibly matches the location of the Miocene Lake Pebas, which was a major consequence of the Miocene/Pliocene marine transgression. The large Pebas zone is expected to harbour a limited number of OTUs derived from upland lineages-those with a history of diversification in areas that remained above inundation level during the late Tertiary (mainly the Guyanan and central Brazilian Precambrian shields plus the eastern Andes foothills) (cf. Nores, 1999; Aleixo, 2004; Aleixo and Rosetti, 2007; Conn and Mirabello, 2007). This was seemingly the case for several Rhodniini lineages (see below).

At this broad scale, the patterns described so far seem compatible with the hypothesis that the Rhodniini first evolved in the humid forests of the Amazon-Orinoco system (Abad-Franch and Monteiro, 2007). Ignoring OTUs not tightly associated with palms at present (the Psammolestes, $R$. paraensis, $R$. neivai, $R$. domesticus, and the central Peruvian forms [group II] of $R$. ecuadoriensis), there also seems to be a rough parallel between Rhodniini OTU counts and Neotropical palm species richness (cf. Bjorholm et al., 2005, 2006). The most conspicuous exceptions (palm-rich/Rhodniinipoor regions) to this trend are the Chocó (the most palm-rich area in the Americas) and the Brazilian Atlantic moist forests, both far from the Amazon-Orinoco core region. This view also receives support from the observation that different Rhodniini species have been recorded from representatives of all four Neotropical palm subfamilies (see Asmussen et al., 2006). The Arecoideae are thought to be of Neotropical origin; many widespread Rhodniini-palm tree associations involve genera within this subfamily (Attalea, Syagrus, Oenocarprus, Leopoldinia, Acrocomia, Astrocaryum, Elaeis, or Cocos), whose current broad-scale patterns of species richness closely match those of the Rhodniini in humid ecoregions. Associations involving Ceroxyloideae (Phytelephas aequatorialis-R. ecuadoriensis and Ph. tenuicaulis-R. pictipes in western and eastern Ecuador, respectively) and Coryphoideae (Copernicia-R. nasutus/neglectus in the Brazilian Caatinga-Cerrado, and Copernicia-R. prolixus/robustus I in the Orinoco) seem to be geographically more restricted. Rhodniini infestation of the widespread Mauritia flexuosa (Calamoideae) appears to be conditioned to the presence of vertebrate nests on the palm crowns (Gurgel-Gonçalves et al., 2004a); the more restricted, fibre-rich $M$. carana can also harbour $R$. robustus populations (Barrett, 1991).
Finer-grained diversification patterns can only be described, and their likely causes hypothesised, by carefully assessing OTU composition across individual ecoregions/areas of endemism and the distribution of each lineage; a plausible description of historical processes at the origin of the observed relationships between areas and lineages may then be derived.

\subsubsection{Major biogeographical clusters-and a widespread OTU (or two)}

$R$. pictipes is the most widespread of the OTUs we analysed. It has been reported to occur in 36 ecoregions across eight areas of endemism, and could have an even wider range. This atypical pattern (the second most widespread OTUs, $R$. robustus II and $R$. prolixus, have been recorded in only 13 ecoregions each) may be an artifact caused by our as yet limited knowledge of population-level diversity in $R$. pictipes. Thus, before Monteiro et al.(2003) uncovered the hidden variation within " $R$. robustus", the species was also considered as a single entity; had we treated all " $R$. robustus" records as such ( $R$. robustus s.l.), our analysis would have disclosed a pattern similar to that observed for $R$. pictipes-species presence in 27 ecoregions (perhaps up to 41) across the same eight areas of endemism (and perhaps in the open/dry corridor too). Because both groups ( $R$. pictipes and $R$. robustus s.l.) are congeneric, largely sympatric, and ecologically similar, we may hypothesise that they must have followed parallel diversification routes under the influence of similar evolutionary stressors. A prediction of this hypothesis is that, for a given molecular marker (and similar sampling coverage), the overall topology of phylogenetic trees of both lineages should be largely comparable, with relatively young (Pleistocene) sub-clades also within $R$. pictipes; in that case, our current view of this species as a widespread, homogeneous taxon would have to be revised. The alternative view implies a recent (post-speciation) range expansion of $R$. pictipes, which would then be a truly widespread species; this hypothesis predicts relatively low genetic diversity with shallow geographical structuring and a unimodal, left-skewed distribution of pairwise mismatch frequencies among mitochondrial gene sequences (Rogers and Harpending, 1992). The recent discoveries of phenotypic and genotypic variants in Venezuela and Colombia (see below) may signal preliminary support for the hypothesis of hidden variation, but the data are still inconclusive.

1.3.2.1. The trans-Andean lineage. Six Rhodniini OTUs (22\%) are exclusively trans-Andean (Rhodnius n.sp. aff. pictipes, $R$. pallescens I and II, $R$. colombiensis, and $R$. ecuadoriensis I and II). R. neivai occurs naturally on both sides of the Andes across the arid ecoregions of the transitional Maracaibo biogeographical province (sensu Morrone, 2006). The rest of OTUs (74\%) are exclusively cis-Andean, with the exception of $R$. prolixus, which was accidentally introduced into trans-Andean subregions (in Colombia, Central America, and southern Mexico) (Dujardin et al., 1998; Monteiro et al., 2003). We thus consider this species as cis-Andean; a possibility exists, however, that natural populations occur in the xeric Guajira-Barranquilla ecoregion.

The diversity within the trans-Andean Rhodnius lineage is only beginning to be ascertained. Mitochondrial cyt $b$ sequence data support the existence of two main clades (the northern $R$. pallescens-colombiensis clade and the southern $R$. ecuadoriensis clade) within this lineage, and suggest that they are sister taxa to the pictipes group of species (Abad-Franch et al., 2003b; Abad-Franch and Monteiro, 2007). The ancestors of the lineage probably dispersed across the northern part of the (then low) Eastern Cordillera of the Colombian Andes in the Miocene, and became isolated with the subsequent rapid uplift $\sim 5$ million years ago (GregoryWodzicki, 2000; Abad-Franch et al., 2003b; Ribas et al., 2005). 
R. pallescens belongs to a complex of three moderately divergent lineages: one mainly from northern Colombia, one mainly from Central America, and an apparently endemic species from the Magdalena Valley dry forests known as $R$. colombiensis (Abad-Franch et al., 2003b; NJO and FAM unpublished). All these lineages share their preferred ecotope, the palm Attalea butyracea.

$R$. ecuadoriensis occurs only in Ecuador and northern Peru, where it survives under a wide range of climatic conditions (Abad-Franch et al., 2001; Cuba Cuba et al., 2002). Northern populations have adapted to Phytelephas aequatorialis palms, which are endemic to the Western Ecuador moist forests but also occur in the southern half of the Northwestern Andean montane forests. The two sister clades within the trans-Andean Rhodnius lineage (pallescens-colombiensis and ecuadoriensis) are, therefore, apparently allopatric, probably as a consequence of Pliocene orogenic vicariance (Gregory-Wodzicki, 2000; Abad-Franch et al., 2003b; Ribas et al., 2005). Southern Ecuadorian populations of $R$. ecuadoriensis are strongly synanthropic, especially across the inter-Andean temperate valleys (Grijalva et al., 2005). Peruvian populations south of the Tumbes/Piura dry forests belong to a distinct, relatively young (Pleistocene) lineage whose sylvatic ecotopes in the semi-arid Andean ecoregions (and perhaps the northernmost wet Puna), where native palms are rare or absent, remain to be described. They are commonly found infesting households, and a few records suggest that they may also occupy hollow trees (Cuba Cuba et al., 2002).

1.3.2.2. Orinoco-Guyana-Imerí. One particular trait of the Orinoco area of endemism is its ecoregional diversity. Small, welldifferentiated ecoregions cluster around the geologically and climatically complex northern and eastern limits of the Orinoco system (WWF-TNC, 2001). Ecological segregation, eventually leading to speciation, can, therefore, be postulated to have had an important role in this subregion. A prediction of this hypothesis is that a relatively large amount of endemic species should occur in the area, and the Rhodniini dataset provides partial support to this view.

Apart from $R$. neivai (endemic to the Maracaibo system), three representatives of the 'robustus lineage' occur in the Orinoco: $R$. prolixus, $R$. robustus I, and $R$. robustus IV (Monteiro et al., 2003; Pavan and Monteiro, 2007). The distribution and relationships of these robustus genotypes suggest that $R$. robustus IV evolved in the Guyanan area of endemicity and later colonised the northern Orinoco system. $R$. prolixus (which occurs in both Copernicia and Attalea palms) and $R$. robustus I seem on the contrary to share a recent common ancestor that lived in the seasonally dry Orinoco lowlands; they are closely related to the newly discovered $R$. robustus V from Imerí (Abad-Franch and Monteiro, 2007). A vicariant Psammolestes population (Ps. arthuri) is a narrow endemic to the Orinoco system open woodlands and savannahs.

The relationships between natural populations of $R$. pictipes from northwestern Venezuela (particularly from areas north of the Cordillera de Mérida) and Rhodnius n.sp. aff. pictipes (from the relatively nearby Sierra Nevada de Santa Marta) have not been determined, but it would not be surprising if they belonged to the same taxon, which would then count as a subregional endemism. A recent revision showed that several morphological and chromatic traits, including male genitalia structures, separate northwestern Venezuelan "pictipes" material (originally from the state of Lara) from descriptions based on Amazonian specimens (Aldana et al., 2003).

At least three OTUs occur in both the Orinoco and the Guyanan areas of endemicity: $R$. robustus (IV), the widespread $R$. pictipes, and $R$. prolixus (which occurs in the transitional zones between the Llanos and the Guyanan moist forests). $R$. robustus $\mathrm{V}$ may be present along the boundary between the Imerí and the Guyanan areas, but the potential barrier effect of the Negro River has not been evaluated. $R$. amazonicus appears on the other hand to be a narrow Guyanan endemic. $R$. paraensis occurs both in the Guyanan area and in eastern ecoregions south of the Amazon, and $R$. brethesi has often been recorded in the Negro River campinaranas, where it infests piaçava fibre palms (Leopoldinia piassaba).

The Imerí area of endemism corresponds to a single ecoregion that encompasses the moist forests between the Negro and the Japurá/Solimões Rivers. Only one Rhodniini OTU (R. robustus V) may be suspected of representing a narrow endemic to this area, but we have no information as to its actual distribution patterns (cf. AbadFranch and Monteiro, 2007). R. pictipes and $R$. brethesi also occur in Imerí. It seems likely that $R$. robustus IV is present as well in this ecoregion, but the considerations on the barrier effect of the Negro River (above) also apply here. The presence of $R$. robustus II in the easternmost part of the Imerí is also plausible.

1.3.2.3. Napo. Apart from what appears to be an evolutionarily old narrow endemic (Rhodnius n.sp. aff. robustus) and a widespread species ( $R$. pictipes), the OTU composition of the Napo area of endemism seems to be transitional between the Orinoco-GuyananImerí and the Inambari-Rondônia clusters. It shares 1-3 OTUs with the former ( $R$. brethesi and perhaps $R$. dalessandroi and $R$. robustus $\mathrm{V}$ ) and 1-2 OTUs ( $R$. robustus II and perhaps $R$. robustus V) with the latter.

1.3.2.4. Inambari-Rondônia. The presence of $R$. brethesi in areas south of the Marañón/Solimões/Amazonas River (Lent and Wygodzinsky, 1979; Galvão et al., 2003) is somewhat dubious; this species seems to be associated with $L$. piassaba palms, which seem in turn restricted to the upper-middle Negro and upper Orinoco rivers (Henderson et al., 1995). Ps. tertius is present in the Mato Grosso dry forests and the Cerrado, which border the Rondônia area of endemism to the east and southeast. Ps. coreodes may occur in southern Inambari, particularly along the boundary with the Chiquitania dry forests. $R$. pictipes is present in most of this area cluster, but appears to be progressively substituted by $R$. stali in the southwestern fringe, which corresponds to the western limit of the central Brazilian shield. There, $R$. stali appears to be associated with Attalea phalerata palms (cf. Matías et al., 2003). $R$. robustus II is widespread across Inambari-Rondônia, and $R$. robustus III is also present in the northeastern tip (Pavan and Monteiro, 2007).

1.3.2.5. Pará-Belém. The rich Rhodniini fauna of the Pará-Belém ecoregional cluster seems to be largely the result of secondary immigration of OTUs evolved elsewhere, with a relatively small contribution, if any, of local diversification. The specific status of the only narrow endemic, $R$. milesi, needs to be confirmed; the original description emphasised diagnosis based upon comparison with $R$. dalessandroi while ignoring obvious similarities with members of the robustus-neglectus-nasutus group (Valente et al., $2001)$. $R$. robustus III appears to be native of this area, but occurs also in the Maderia-Tapajós forests (see above). Other species are shared with either the Guyanan area ( $R$. paraensis, $R$. robustus IV), with the open/dry corridor ( $R$. neglectus, $R$. nasutus, Ps. tertius), with Inambari-Rondônia ( $R$. robustus $\mathrm{II})$, or with most of Amazonia $(R$. pictipes). These patterns of OTU sharing results in the unstable position of the Belém area of endemism in the cladograms of Fig. 2(C), where it appears as a sister area to either the Guyanan or the ParáRondônia clade, depending upon which OTUs are analysed (only those actually recorded in each area $v s$. those recorded and those probably also present).

1.3.2.6. Open/dry corridor. At least four species of Rhodniini ( $R$. neglectus, $R$. nasutus, Ps. tertius, and Ps. coreodes) probably evolved 
in the vast 'arid diagonal' of central South America (Ab'Sáber, 1977), but none of them remained restricted to it to become a narrow endemic. $R$. neglectus is widespread across the Cerrado and the dry forests of this corridor, where it occupies palms of at least five genera and bird nests but may also invade and sporadically colonise artificial structures (Gurgel-Gonçalves et al., 2008; see below). There are indications that geographic populations of this species are genetically very little structured, which could be explained by either a recent range expansion of a formerly localised, homogeneous gene pool or by an extreme vagility of the species (perhaps related to the passive carriage of eggs or small nymphs by dispersing birds) (RG-G, unpublished data). $R$. nasutus seems to be endemic to the Caatinga xeric shrublands, where Copernicia palms are often infested, but may also occupy other palm genera in more humid ecoregions and in the relict premontane forest on the Caatinga crystalline ridges and inselbergs (Costa, 2003; Dias, 2007; see below). The two southern Psammolestes species (Ps. tertius in the Cerrado and Ps. coreodes in the Chaco) are closely related to each other, and probably share a common ancestor with the northern Ps. arthuri (see below). Trans-Amazonian vicariants have been identified in several taxonomic groups (e.g., QuijadaMascareñas et al., 2007), and are probably also present in other triatomines (e.g., T. maculata; see dos Santos et al., 2007; AbadFranch and Monteiro, 2007). Indeed, the sister-group relationship of $R$. neglectus and the Orinoco-northern Amazon clade (R. prolixus$R$. robustus I- $R$. robustus V) (Monteiro et al., 2000 and unpublished data) suggests that a similar mechanism, even if perhaps over different time-frames, underlies the evolution of these vicariant groups. Under this scenario, $R$. nasutus would have become isolated from its stem lineage before the diversification of the robustus-prolixusneglectus clade got started (Monteiro et al., 2000). The open/dry corridor appears as basal to the rest of cis-Andean areas (together with the Atlantic/humid corridor, below) when area relationships are estimated using only factual OTU records [Fig. 2(A) and (C)]; less restrictive analyses (using all OTUs) tend to cluster these southern corridors with neighbouring Amazonian areas [Fig. 2(C)], likely because of spill-over of species across transitional border zones.

1.3.2.7. Atlantic/humid corridor (and a closing note on the Psammolestes). $R$. domesticus is the only narrow endemic to this area. It seems to represent an old lineage that evolved independently for several million years in the moist Atlantic forests of centralsouthern Brazil (mainly along the Serra do Mar range), which were connected to Amazonian lowland moist forests until increasing aridity began to foster the expansion of open formations in the Miocene (Cox and Moore, 2000; Monteiro et al., 2000; Costa, 2003; Abad-Franch and Monteiro, 2007). Southern and southeastern populations of $R$. neglectus also occur in the fringes of this corridor, particularly in the interior forests that border the Cerrado to the east.

Ps. coreodes is the southernmost representative of the Rhodniini; it has been recorded in the humid Chaco and in the savannahs of the Argentinean Paraná-Uruguay interfluvial. As for the other two species of this genus, it appears to have specialised in exploiting protected bird nest habitats. Available records suggest a preference for the nests of the ovenbirds (Furnariidae) Phacellodomus spp. (all three Psammolestes), Anumbius sp.(Ps. tertius), and Pseudoseisura sp. (Ps. coreodes), even if other nests (of Dendrocolaptidae, Psittaciidae and, more rarely, Emberizidae) may also be colonised occasionally (Lent and Wygodzinsky, 1979; Carcavallo and Martínez, 1985; Gurgel-Gonçalves et al., 2004a). Phacellodomus, Anumbius, and Pseudoseisura all build large, enclosed vegetative nests in the open, a trait most likely derived and relatively recently evolved within the highly diverse family Furnariidae (among which cavity nests are probably plesiomorphic) (Irestedt et al., 2006). Phacellodomus and
Anumbius belong to the subfamily Synallaxinae, the former being basal, and phylogenetic reconstructions suggest that Pseudoseisura, classically ascribed to the Phylidorinae, also belongs to a derived synallaxine clade (Irestedt et al., 2006). Today, the Psammolestes and the synallaxines are both trans-Amazonian vicariants. We may, therefore, tentatively propose that the Psammolestes arose as an individual lineage in association with ancestral synallaxine furnariids building large vegetative nests in open, semi-arid woodland and savannahs.

\subsection{Conclusions}

Albeit still incomplete, our coarse-grained overview of macroscale biogeographical and ecological patterns among the Rhodniini provides some comprehensive insights as to what major mechanisms and processes probably underlie biogeographical, ecological, and genetic diversification in this tribe of triatomines. Acknowledging that we traded detail for generality, and that many of our proposals are 'mere' hypotheses, we now summarise the seven main points we derive from our results.

(1) The Rhodniini (which should be considered as a single genus) first evolved in the humid forests corresponding to the contemporary Amazon-Orinoco meta-system, probably in association with palms and palm tree fauna (Gaunt and Miles, 2000, 2002; Abad-Franch and Monteiro, 2007). Two major extant lineages derived from this ancestral stock: the 'pictipes lineage' (including the trans-Andean endemic taxa) and the 'robustus lineage' (including the Psammolestes) (Abad-Franch and Monteiro, 2007).

(2) OTU counts per ecoregion suggest (without conclusively supporting) that particularly dynamic diversification events took place on non-flooded areas during the Miocene/Pliocene marine transgression, with secondary colonisation of suitable lowland forest ecoregions (particularly in western Amazonia) by several lineages. Most of the observed OTU richness "hotspot" ecoregions seem to correspond to contact zones where dispersing taxa became sympatric after having evolved elsewhere.

(3) Ecological segregation/diversification was probably important along the northern tip of the Andes and in the neighbouring savannahs and dry lowland forests on both sides of the cordillera. The clearly vicariant clade of endemic transAndean species probably originated in this subregion in the late Miocene and subsequently colonised a variety of ecoregions from Central America to northern Peru, diversifying under the influence of Miocene/Pliocene Andean orogeny and, subsequently, of Pleistocene climatic fluctuations (Abad-Franch et al., 2003a,b; Nores, 2004; Ribas et al., 2005).

(4) Even if still speculative, we may put forward the hypothesis that the 'pictipes lineage' first arose in the Orinoco-Guyanan area of endemism in the Miocene, gave rise to the ancestors of the trans-Andean lineage, and later dispersed southwards. The lineages that gave rise to Rhodnius n.sp. aff. pictipes (Sierra Nevada de Santa Marta and perhaps Cordillera de Mérida), to $R$. amazonicus, $R$. paraensis, and $R$. brethesi (Guyanan-Imerí), and to $R$. stali (westernmost central Brazilian shield) could have become isolated as a consequence of the Miocene/Pliocene marine transgression (Nores, 1999, 2004). The wide distribution of $R$. pictipes may be the result of a real post-speciation range expansion or may be an artifact caused by an as yet inadequate sampling of the diversity within this taxon; each of these alternative hypotheses imply testable predictions that can be suitably addressed by phylogenetic and population genetics analyses of molecular data (Abad-Franch and Monteiro, 2005). 
(5) Several relatively old (probably starting in the late Miocene and stretching into the Pliocene) vicariant events led to the isolation of endemic 'robustus lineage' taxa in the Brazilian Atlantic forests ( $R$. domesticus), the Maracaibo basin ( $R$. neivai), the equatorial Andes foothills (Rhodnius n.sp. aff. robustus), and the Caatinga ( $R$. nasutus). All these peripheral isolates correspond to deep branches within the lineage (Monteiro et al., 2000 and unpublished data); the fact that each of these branches has only one terminal taxon suggests a role for local extinction of former sister lineages. A trans-Amazonian vicariant lineage, Psammolestes, probably predates these early events and may have evolved in association with synallaxine ovenbirds (Furnariidae).

(6) More recent (late Pliocene-Pleistocene) cladogenetic events led to the splitting of the robustus-neglectus-prolixus group, giving rise to (i) a second trans-Amazonian vicariant ( $R$. neglectus $+[R$. prolixus- $R$. robustus $\mathrm{I}-\mathrm{R}$. robustus $\mathrm{V}])$; (ii) a western clade $(R$. robustus II, which would have colonised Inambari-Rondônia secondarily); and (iii) a younger Guyanan-southeastern Amazonian clade ( $R$. robustus IV and $R$. robustus III). These patterns were interpreted as providing support to the Pleistocene refugia hypothesis (Monteiro et al., 2003) and, in a later reassessment, as compatible with the marine transgression hypothesis (Conn and Mirabello, 2007); they might in fact be a combination of both, with early cladogenesis related to the marine transgression and later diversification related to climate shifts and their consequences on the relative distribution, size, and connectivity of moist forests and open formations (Hooghiemstra and Van Der Hammen, 1998).

The overall biogeographical-evolutionary patterns of the Rhodniini are complex but not necessarily unintelligible. As more data on the phylogenetic relationships among OTUs accrue (including data from rare species such as $R$. paraensis or $R$. amazonicus, from populations of widespread species from as yet unsampled areas, and more precise dating of nodes in phylogenetic trees), our ability to relate their patterns of descent with the historical biogeography of the areas they live in will keep improving. The relative roles of vicariance, long-distance dispersal, range expansion, and local extinction will be progressively clarified, and a coherent picture will emerge against which to test new discoveries and theoretical elaborations. The information conveyed by this picture (where there are more species, where do certain species occur and where they do not, and why) will certainly help define more efficient vector control and surveillance strategies. The recent proposal that ecological and evolutionary factors should be partitioned to suitably investigate the process of adaptation of sylvatic triatomines to human environments (Abad-Franch and Monteiro, 2007) is an example of how these efforts may foster our ability to confront the challenge of keeping Chagas disease incidence below acceptable rates in the long run. On the other hand, it is important to recognise that the ecological processes probably involved in the onset of triatomine synanthropism (habitat loss, food shortage, host switch, or a higher frequency of flight dispersal by adult bugs), and the responses we can devise in order to lessen human-vector contact, all share the attribute of being mesoscale phenomena. Triatomine populations adapt to anthropogenic environmental changes at the landscape level, and vector control-surveillance systems are designed and put into practice at the landscape level. It follows that many of the questions we should ask (and help answer) to improve the odds of successful disease control are mesoscale (landscape) ecological questions: what vector species are present in a given locality or subregion?; which of those species can invade or colonise human environments, and where?; what are the main ecotopes where natural populations occur?; what are the main behavioural traits of those populations?; and, finally, where and how should entomological surveillance resources be allocated? We now present an example of mesoscale investigation that addresses this sort of questions, focusing on two secondary vectors that occur throughout the open/dry corridor of northeastern and central Brazil, the near-sibling $R$. neglectus and $R$. nasutus.

\section{Vector systematics, ecology, and behaviour at the mesoscale: Rhodnius neglectus and $R$. nasutus in palm trees of semi-arid Brazilian ecoregions}

\subsection{Alpha-systematics of near-sibling taxa: geometric morphometrics of Rhodnius neglectus and $R$. nasutus}

\subsubsection{Introduction}

$R$. neglectus and $R$. nasutus are two near-sibling species belonging to the 'robustus lineage'. Both are primarily associated with palm trees in open formations with long dry seasons in central and northeastern Brazil, and both invade and sporadically colonise human environments. $R$. neglectus occurs across the open/dry corridor (mainly in the Cerrado) and in several neighbouring ecoregions. $R$. nasutus is apparently endemic to the drier Caatinga of northeastern Brazil, but has also been collected in the Maranhão babaçu forests (southeastern Amazonia) and in the Northeast Brazil dry forests (Table 1). These two species may, therefore, occur in sympatry in transitional areas between their respective core ecoregions.

$R$. neglectus and $R$. nasutus can be identified by comparing chromatic patterns (of the body and antennae), and also differ in their overall size (Lent and Wygodzinsky, 1979). Chromatic variation is, however, present in both species (Barrett, 1996), and size-related traits are known to be sensitive to environmental stress in triatomines (Dujardin et al., 1999; Abad-Franch et al., 2003a). Finally, Harry (1993) detected no clear-cut differences in male genitalia structures between $R$. neglectus and $R$. nasutus. A variety of molecular markers can be used to identify dubious specimens, but costly and complex procedures are involved that make these techniques unlikely to become routinely applied in vector surveillance in the near future. Problematic triatomine species pairs can also be separated by numerical analysis of quantitative phenotypic traits. Multivariate analyses of morphometric data can also be complex, but have the key advantage of making use of digital pictures of anatomical structures (wings and/or heads) that can be taken by surveillance teams and sent by electronic media to a reference laboratory. There, the analyses can be run and a response produced within a few hours. Several recent studies show how geometric morphometric approaches provide particularly valuable tools for triatomine alpha-systematics, and suggest that they could significantly strengthen vector surveillance systems (e.g., Matías et al., 2001; Villegas et al., 2002; Gumiel et al., 2003; Schachter-Broide et al., 2004; Dujardin et al., 2007; Feliciangeli et al., 2007; GurgelGonçalves et al., in press).

We tested the performance of geometric morphometrics in identifying adult bugs collected from palms in the state of Bahia (where Cerrado-Caatinga ecotones are common) as R. neglectus or $R$. nasutus. We compared these specimens with reference populations of known specific status, assessing whether size and shape patterns can be used as taxonomic markers for this species pair.

\subsubsection{Materials and methods}

Wings ( $n=172)$ and heads ( $n=180)$ from three $R$. neglectus and two $R$. nasutus populations were analysed (Table 2 ). $R$. neglectus samples were collected from Mauritia flexuosa palm trees (see Gurgel-Gonçalves et al., 2003, 2004a for details). The R. neglectus reference sample came from a colony founded with topotype spec- 
Table 2

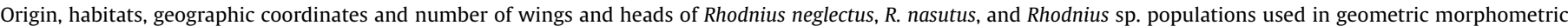
analyses.

\begin{tabular}{|c|c|c|c|c|c|}
\hline Population & Origin $^{a}$ & Habitat & Coordinates & Wings & Heads \\
\hline Rhodnius neglectus ${ }^{\mathrm{b}}$ & Araguaína, TO & Palm trees (Mauritia flexuosa) & $07^{\circ} 28^{\prime} \mathrm{S}, 48^{\circ} 22^{\prime} \mathrm{W}$ & 25 & 32 \\
\hline Rhodnius neglectus ${ }^{\mathrm{b}}$ & Alto Paraíso, GO & Palm trees (M. flexuosa) & $14^{\circ} 09^{\prime} \mathrm{S}, 47^{\circ} 33^{\prime} \mathrm{W}$ & 26 & 32 \\
\hline Rhodnius neglectus ${ }^{\mathrm{b}}$ & Buritizal, SP & Palm trees (M. flexuosa) & $20^{\circ} 11^{\prime} \mathrm{S}, 47^{\circ} 42^{\prime} \mathrm{W}$ & 29 & 31 \\
\hline Rhodnius neglectus ${ }^{\mathrm{c}}$ & Uberaba, MG & Laboratory colony & $19^{\circ} 32^{\prime} \mathrm{S}, 48^{\circ} 01^{\prime} \mathrm{W}$ & 11 & 6 \\
\hline Rhodnius nasutus ${ }^{\mathrm{d}}$ & Meruoca, CE & Palm trees (Attalea speciosa) & $03^{\circ} 31^{\prime} \mathrm{S}, 40^{\circ} 25^{\prime} \mathrm{W}$ & 28 & 30 \\
\hline Rhodnius nasutus ${ }^{\mathrm{d}}$ & Sobral, CE & Palm trees (Copernicia prunifera) & $03^{\circ} 47^{\prime} \mathrm{S}, 40^{\circ} 24^{\prime} \mathrm{W}$ & 27 & 30 \\
\hline Rhodnius sp. ${ }^{\mathrm{b}}$ & Curaçá, BA & Palm trees (C. prunifera) & $08^{\circ} 59^{\prime} \mathrm{S}, 39^{\circ} 54^{\prime} \mathrm{W}$ & 17 & 10 \\
\hline Rhodnius sp. ${ }^{\mathrm{b}}$ & São Desidério, BA & Palm trees (M. flexuosa) & $12^{\circ} 22^{\prime} \mathrm{S}, 45^{\circ} 51^{\prime} \mathrm{W}$ & 9 & 9 \\
\hline
\end{tabular}

a Locality and state: TO Tocantins, GO Goiás, SP São Paulo, MG Minas Gerais, CE Ceará, and BA Bahia.

b Sylvatic populations.

c Colony from the Instituto René Rachou, Fiocruz (founder specimens collected in the type locality).

d F1 generation from sylvatic populations.

imens and kept at the Centro de Pesquisas René Rachou (Fiocruz, Brazil). Other bugs unambiguously identified as R. neglectus (from the states of Tocantins, São Paulo, and Goiás) were also used in the comparisons. R. nasutus populations were collected from either A. speciosa or Copernicia prunifera palms in the core area of the species range (state of Ceará). Bugs were identified after Lent and Wygodzinsky (1979), with the exception of the samples whose specific status we aimed at testing (from Curaçá and São Desidério, state of Bahia), which were treated as 'unidentified specimens' in the analyses (Rhodnius sp. in Table 2).

Right forewings were mounted on microscope slides and digitally scanned. Six type I (venation intersection) and one type II landmarks (Bookstein, 1991) were digitised. Heads were photographed with a digital camera adapted to a stereomicroscope ( $25 \times$ magnification). Eight head landmarks were used in morphometric analyses. Landmark coordinates were recorded using the software tpsDig 1.18 (Rohlf, 1999a).

We used "centroid size" (CS), an isometric size estimator derived from coordinate data (Bookstein, 1991), to analyse size variation. CS values were extracted from coordinate matrices using tpsRelw version 1.18 (Rohlf, 1999b) and log-transformed. The generalised Procrustes analysis superimposition algorithm (Rohlf, 1996) was used to compute non-uniform (partial warps) and uniform components, which measure the deformation of each individual structure in relation to a least-squares consensus configuration. Both uniform and non-uniform components were used in subsequent statistical comparisons of the shape patterns of both species. Shape variables were computed using tpsRelw 1.18 (Rohlf, 1999b).

Size variation (wing and head CS values) among populations was explored by means of ANOVA and Tukey tests (alpha $=0.01$ ). Shape variables derived from partial warps were used as input for multivariate Discriminant Function Analysis (DFA). We explored the relationships between unidentified specimens and our $R$. neglectus and $R$. nasutus reference populations in terms of shape patterning. Populations of known status ( $R$. neglectus and $R$. nasutus) were grouped a priori for computing discriminant scores, while unidentified specimens from the sate of Bahia were incorporated $a$ posteriori into the analyses. Discriminant scores were then used to construct factorial maps displaying the distribution of specimens and populations in the shape space defined by the two discriminant factors. Convex hulls (polygons enclosing all specimens within each group) were overlaid on the plots and individual dots removed-except for unidentified specimens whose position we wanted to examine. Finally, we measured the contribution of size to shape variation (allometry) using multiple regression of shape discriminant factors against CS values (wings and heads). We used contingency table analysis and Kappa statistics (Landis and Koch, 1977) to assess reclassification of specimens to their original putative groups. DFA, ANOVA, multiple regression, and Tukey tests were computed with Statistica ${ }^{\circledR}$ (StatSoft Inc., Tulsa, OK, USA). Kappa statistics were computed with JMP 4.0.2 ${ }^{\circledR}$ (SAS Institute Inc., Cary, NC, USA).

\subsubsection{Results and discussion}

Clear size differences were detected among Rhodnius species/populations for both wings and heads and for both males and females (wings: $\sigma^{7}$ ANOVA $F_{7,86}=15.1 ; p<0.01$; $q$ ANOVA $F_{7,70}=28.5 ; p<0.01 ;$ heads: or ANOVA $F_{6,76}=13.7 ; p<0.01$; ANOVA $F_{6,75}=39.8 ; p<0.01$ ). Average CS was larger in $R$. neglectus (CSwing $=0.68 \pm 0.03$ and CShead $=0.58 \pm 0.03$ ) than in $R$. nasutus $(C S w i n g=0.66 \pm 0.03$ and CShead $=0.55 \pm 0.02)(t$-test; $p<0.01)$. Rhodnius sp. specimens from Curaçá were markedly smaller than those from São Desidério ( $t$-test; $p<0.01$ ). Further analyses (see below) suggested, however, that the Curaçá sample encompassed more than a single species.

Both wing (Fig. 3) and head shape patterning revealed significant differences between $R$. neglectus and $R$. nasutus. DFAderived correct reclassification scores were high for both head $($ Kappa $=0.90)$ and wing $($ Kappa $=0.88)$ shape variables. Unidentified specimens from São Desidério were all indistinguishable from our $R$. neglectus reference populations, including the Fiocruz topotypic stock. Some specimens from Curaçá fell also within the $R$. neglectus cluster, while others were more similar to $R$. nasutus and a few had an intermediate shape pattern (Fig. 3). This is compelling evidence that both species are sympatric (and infest $C$. prunifera palms) in Curaçá, and calls for research on between-species ecological interactions. We found no significant allometric trend in wings $\left(R^{2}=0.02 ; p<0.01\right)$, but the second head shape discriminant factor (DF2) was significantly correlated with CS $\left(R^{2}=0.29 ; p<0.01\right)$.

Entomologists working in Chagas disease vector surveillance in northeastern Brazil should be aware that $R$. neglectus and $R$. nasutus can occur in sympatry in the state of Bahia and probably in other transitional zones between the Cerrado and the Caatinga. Our geometric morphometric analyses could be envisaged as an example of how these tools can be used to optimise surveillance systems. The results show how species-level determination in the context of vector surveillance could be significantly enhanced if a reference morphometric dataset were built against which unidentified specimens could be compared.

\subsection{The ecology and behaviour of Rhodnius neglectus and $R$. nasutus in palms trees of the Brazilian open formations}

\subsubsection{Introduction}

Lent (1954) described $R$. neglectus based on bugs collected from Attalea palms in central Brazil (Uberaba, Minas Gerais) that had been previously identified as $R$. prolixus. Subsequently, several studies showed that the species was common in palm trees across 


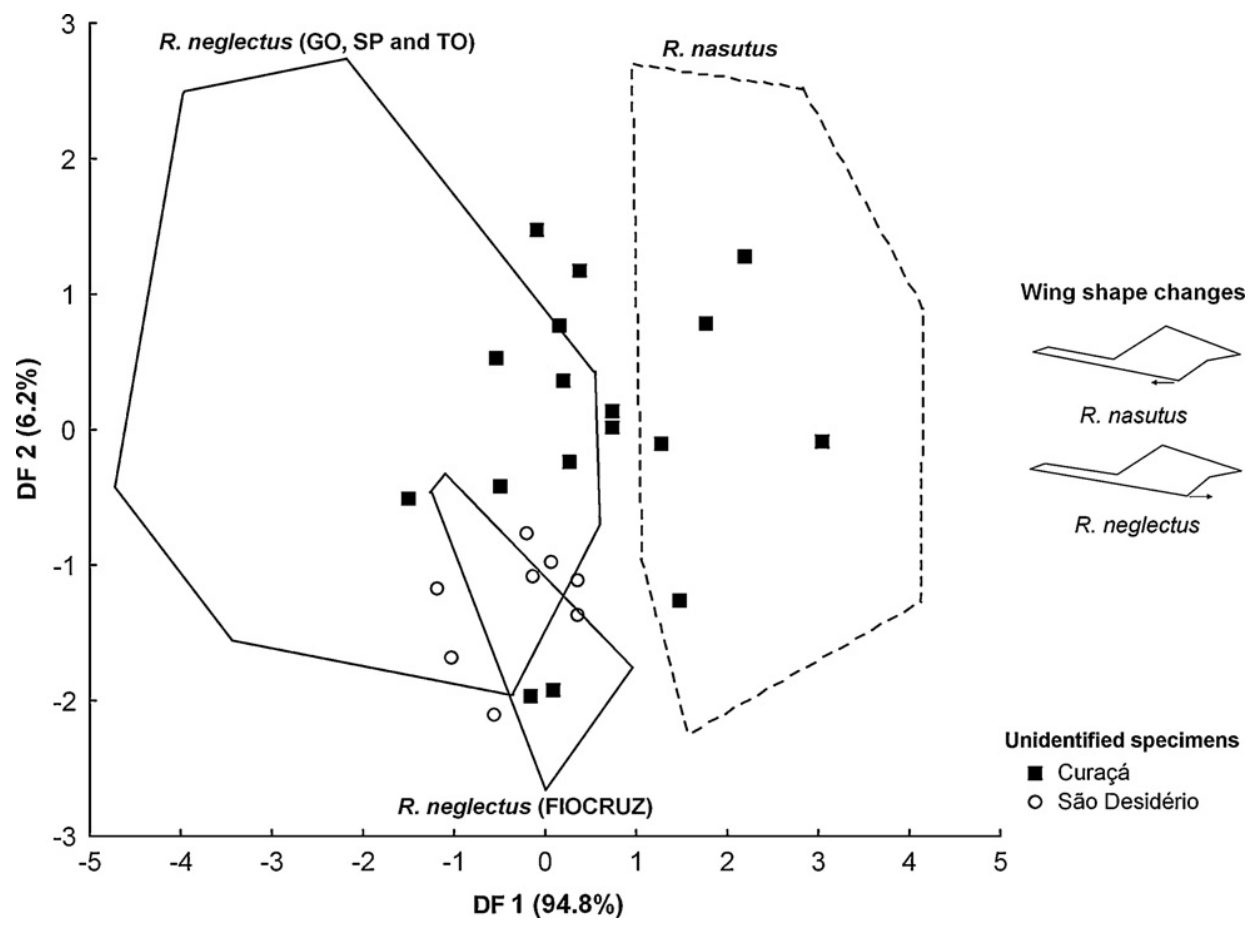

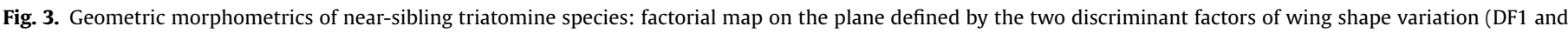

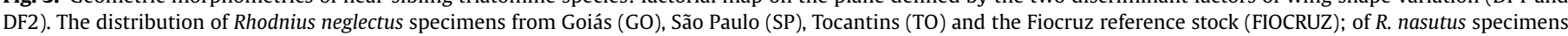

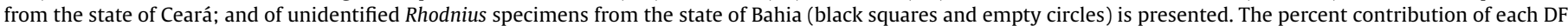

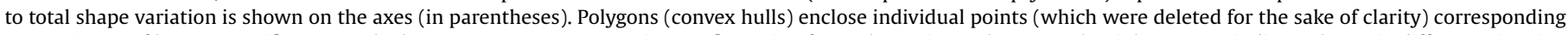

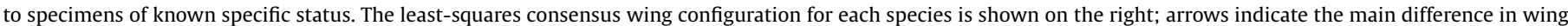
shape (end of the postcubital vein) between $R$. neglectus and $R$. nasutus.

central Brazil, and particularly in the Cerrado (Barretto, 1979; Diotaiuti and Dias, 1984; Teixeira et al., 2001; Gurgel-Gonçalves et al., 2003, 2004a). The species has since then been reported from 12 Brazilian states (Carcavallo et al., 1999; Galvão et al., 2003). Its synanthropic behaviour was described in early works-even before its description, when it was reported as R. prolixus (e.g., Martins et al., 1940; Pellegrino, 1950; Correa, 1968). Most specialists agree that $R$. neglectus is not a major vector of human Chagas disease, in spite of its wide distribution and its ability to colonise artificial environments (mainly chicken houses and dovecotes) (Barretto et al., 1968; Barretto, 1976; Diotaiuti and Dias, 1984). R. neglectus appears in the list of triatomine species more frequently collected in households by Chagas disease control agents in eight Brazilian states (Dias, 2002), and plays an important role in the maintenance of $T$. cruzi transmission in the wild (Gurgel-Gonçalves et al., 2004b). In the periphery of Belo Horizonte (a 2.5 million-people city in Minas Gerais), up to $60 \%$ of the dominant Acrocomia aculeata palms may be infested by $R$. neglectus, with a rate of $T$. cruzi infection approaching $16 \%$; the finding of bugs within households is nonetheless considered rare in the region (Diotaiuti and Dias, 1984).

The first evidence of widespread synanthropism in $R$. neglectus was provided by Silveira and coworkers, who surveyed 630 households (130 municipalities) of the Brazilian sates of Goiás and Tocantins (Silveira et al., 1984). $R$. neglecuts specimens were collected in 271 households (93 municipalities); peridomestic structures were infested in $57 \%$ of the households, and bugs were found inside $43 \%$ of houses. Intra-domiciliary colonies were first detected in 1978, and became more common until extensive insecticide spraying campaigns began in 1983. $R$. neglectus is currently a candidate vector in Goiás (Oliveira and Silva, 2007) and over the Pará-Maranhão border (where the landscape is dominated by extensive palm forests frequently infested by $R$. neglectus), but may also be of some importance in other Brazilian states (Silveira et al., 1984; Silva et al., 1999; Guilherme et al., 2001).

Much less is known about the ecology of $R$. nasutus. Its geographical distribution is restricted to the Brazilian northeastern region, including the states of Ceará, Maranhão, Paraiba, Pernambuco, Piauí, and Rio Grande do Norte (Lucena and Lima-Borba, 1977; Carcavallo et al., 1999; Galvão et al., 2003). The core area of this range corresponds to the semi-arid Caatinga, probably the least studied of all Brazilian biomes. Copernicia prunifera (the 'carnaúba' wax palm) is thought to represent the primary natural ecotope of $R$. nasutus, which feeds mainly on birds (Lent and Wygodzinsky, 1979; Forattini et al., 1981; Alencar, 1987; Sarquis et al., 2004). As with $R$. neglectus, this species sporadically invades houses and often colonises peridomestic structures, particularly thatched henhouses (Alencar, 1987; Dias et al., 2000; Sarquis et al., 2004, 2006). In the $1970 \mathrm{~s}-1980 \mathrm{~s}$, R. nasutus ranked fourth among six triatomine species found in artificial environments in the state of Ceará-and became third after the elimination of $T$. infestans in the 1990s (Forattini et al., 1981; Alencar, 1987; Dias, 2007). Because the rates of $T$. cruzi infection tend to be low in this largely ornithophilic species, the contribution of $R$. nasutus to human Chagas disease transmission is generally thought to be minor (Forattini et al., 1981; Alencar, 1987). More recent surveys suggest, however, that over $27 \%$ of $R$. nasutus can be infected by T. cruzi in the state of Ceará, a higher rate than that recorded for other synanthropic vectors such as $T$. brasiliensis (15\%) or T. pseudomaculata (18\%) (Sarquis et al., 2004).

In an attempt to improve our understanding of the main ecological features of these two near-sibling Rhodnius species, we determined infestation rates in a sample of 282 palm trees in five localities within the two major semi-arid ecoregions of centralnortheastern Brazil: the Cerrado and the Caatinga. We aimed at describing the patterns of palm tree infestation in these two open 


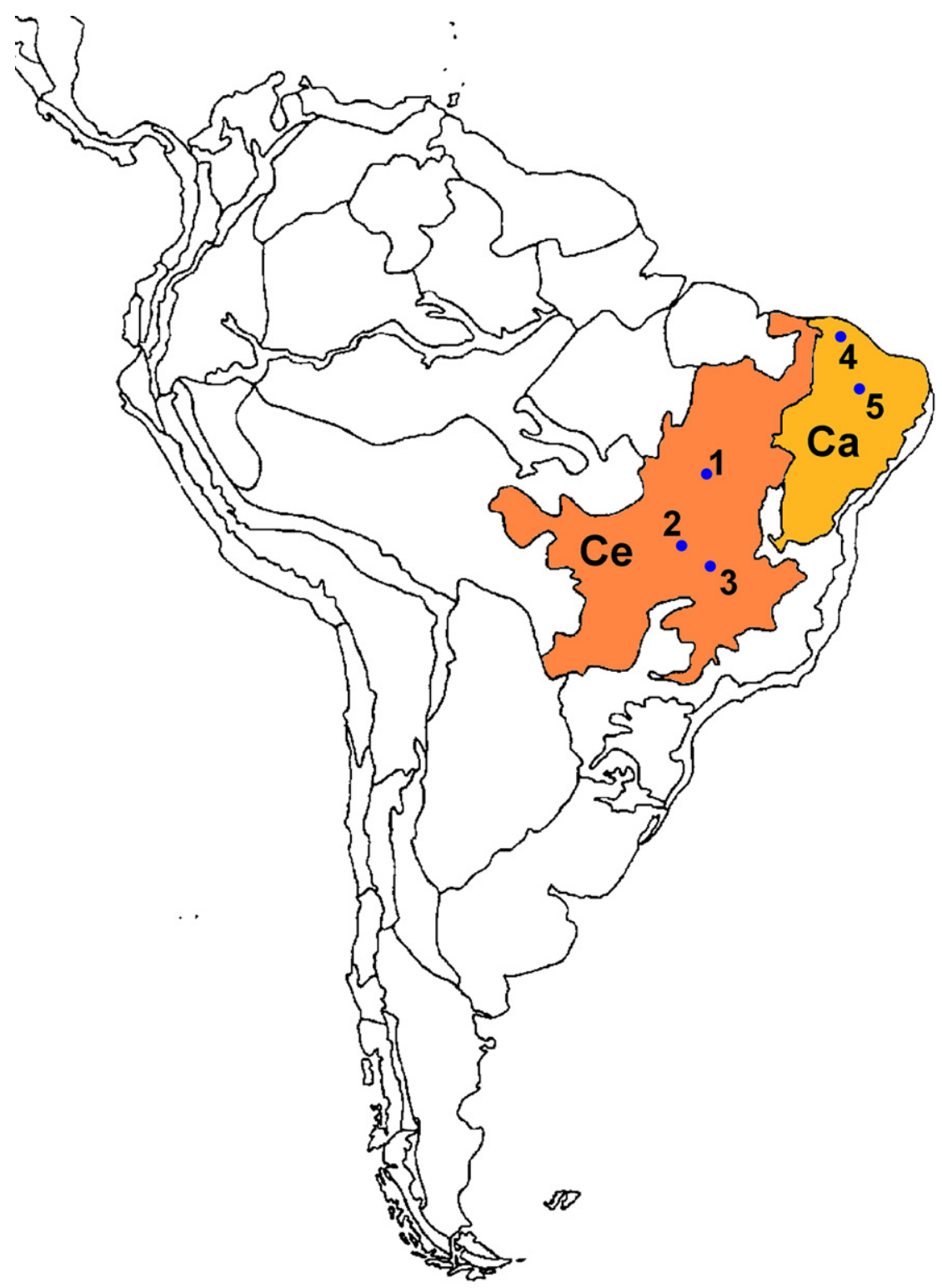

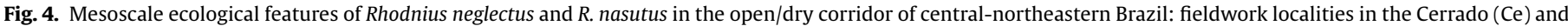

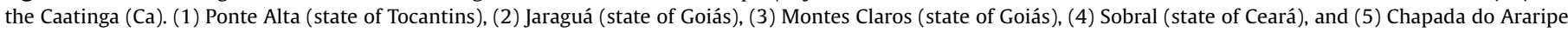
(state of Ceará).

formations, preliminarily testing the null hypothesis that infestation rates are homogeneous among palm species and across localities and ecoregions.

\subsubsection{Materials and methods}

In central Brazil, we surveyed three municipalities where $R$. neglectus displays different degrees of synanthropic behaviour: Jaraguá (state of Goiás), where $R$. neglectus has been reported to breed within houses; Montes Claros (Goiás), where the species was found in peridomestic environments but never inside dwellings; and Ponte Alta (state of Tocantins), from where R. neglectus had never been reported. All three sites are located within the limits of the Cerrado, but Ponte Alta is closer to the Mato Grosso tropical dry forests and southeastern Amazonia (Fig. 4). Most of the municipality of Jaraguá is heavily deforested; native forests are restricted to small pockets within an extensive matrix of crops and pastures from which some palm tree species seem to have become extinct. In contrast, anthropic environmental disturbance has been less exten- sive in Montes Claros and Ponte Alta, where preserved landscapes are still relatively common.

In northeastern Brazil, two areas within the state of Ceará were investigated (Fig. 4). The first study area (municipality of Sobral) is representative of the semi-arid Caatinga, with extensive lowland ( $<100 \mathrm{~m}$ altitude) open formations dominated by Copernicia prunifera palms; more humid forests grow on the slopes and hilltops of crystalline ridges, where Atlantic winds provide moisture throughout the year; $A$. speciosa substitutes $C$. prunifera as the dominant palm in these relict moist forests. The second site (Chapada do Araripe) is also a mountainous area within the Caatinga; the altitudinal gradient is paralleled by vegetation changes from the arid lowlands to the more humid upland forests. The diverse flora of this subregion includes species and communities typical of the Cerrado, Caatinga, and moist Atlantic forests.

In each study site, a sample of dominant palm tree species was felled and dissected for manual collection of triatomines (Diotaiuti and Dias, 1984). A total number of 282 palms of eight species was 
Table 3

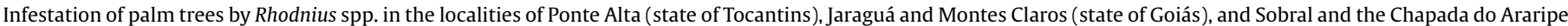
(state of Ceará), Brazil.

\begin{tabular}{|c|c|c|c|c|c|c|c|c|c|c|c|c|c|c|c|c|c|c|}
\hline \multirow[t]{2}{*}{ Palm tree species } & \multicolumn{3}{|c|}{ Ponte Alta ${ }^{a}$} & \multicolumn{3}{|c|}{ Jaraguáa } & \multicolumn{3}{|c|}{ Montes Claros ${ }^{\mathrm{a}}$} & \multicolumn{3}{|c|}{ Sobral ${ }^{b}$} & \multicolumn{3}{|c|}{ Araripe $^{\mathrm{b}}$} & \multicolumn{3}{|c|}{ Total } \\
\hline & $\mathrm{S}$ & I & $\%$ & $\mathrm{~S}$ & I & $\%$ & $\mathrm{~S}$ & I & $\%$ & $\mathrm{~S}$ & I & $\%$ & $\mathrm{~S}$ & I & $\%$ & $\mathrm{~S}$ & I & $\%$ \\
\hline Attalea speciosa & 20 & 16 & 80 & 0 & - & - & 20 & 17 & 85 & 9 & 8 & 88.9 & 10 & 10 & 100 & 59 & 51 & 86.4 \\
\hline Attalea phalerata & 20 & 0 & 0 & 9 & 4 & 44.4 & 20 & 9 & 45 & 0 & - & - & 0 & - & - & 49 & 13 & 26.5 \\
\hline Oenocarpus distichus & 20 & 1 & 5 & 0 & - & - & 0 & - & - & 0 & - & - & 0 & - & - & 20 & 1 & 5 \\
\hline Mauritia flexuosa & 20 & 19 & 95 & 0 & - & - & 20 & 14 & 70 & 0 & - & - & 10 & 9 & 90 & 50 & 42 & 84 \\
\hline Syagrus oleracea & 0 & - & - & 10 & 2 & 20 & 0 & - & - & 0 & - & - & 10 & 9 & 90 & 20 & 11 & 55 \\
\hline Acrocomia aculeata & 20 & 8 & 40 & 7 & 4 & 57.1 & 20 & 10 & 50 & 0 & - & - & 0 & - & - & 47 & 22 & 46.8 \\
\hline Acrocomia intumescens & 0 & - & - & 0 & - & - & 0 & - & - & 0 & - & - & 10 & 7 & 70 & 10 & 7 & 70 \\
\hline Copernicia prunifera & 0 & - & - & 0 & - & - & 0 & - & - & 17 & 10 & 58.8 & 10 & 8 & 80 & 27 & 18 & 66.7 \\
\hline Total & 100 & 44 & 44 & 26 & 10 & 38.5 & 80 & 50 & 62.5 & 26 & 18 & 69.2 & 50 & 43 & 86 & 282 & 165 & 58.5 \\
\hline
\end{tabular}

${ }^{\text {a }}$ Localities where only Rhodnius neglectus was collected.

b Localities where only $R$. nasutus was found; $S=$ number of palm trees surveyed; $I=$ number of palm trees infested; \%= percent palm infestation.

surveyed: A. phalerata ('aricuri'), A. speciosa ('babaçu'), Oenocarpus distichus ('bacaba'), Mauritia flexuosa ('buriti'), Acrocomia aculeata ('macaúba'), Acrocomia intumescens ('macaúba-barriguda'), Syagrus oleracea ('guariroba'), and Copernicia prunifera ('carnaúba') (Table 3). Palm identification followed Lorenzi et al. (1996). Infestation rates were tested for random variation among palm species and localities using contingency table analysis and Chi-squared tests as implemented in JMP 4.0.2 ${ }^{\circledR}$ (SAS Institute Inc., Cary, NC, USA).

Bugs were identified after Lent and Wygodzinsky (1979) and their gut contents and salivary glands examined for trypanosomatids under a light microscope. We performed precipitin reactions (Siqueira, 1960) to identify bloodmeals in a subset of 351 bugs using a battery of nine antisera (human, bird, cat, opossum, dog, pig, bat, rodent, and lizard).

\subsubsection{Results and discussion}

We collected triatomines in all five study areas. They were identified as either $R$. neglectus (bugs from Goiás and Tocantins) or $R$. nasutus (bugs from Ceará). Overall palm infestation index was 58.5\% (95\% confidence interval $=53 \%-64 \%$, with highly significant differences between palm species (Pearson $X^{2}=80.6,7$ d.f., $p<0.0001$ ) and across study sites (Pearson $X^{2}=30.3,4$ d.f., $p<0.0001$ for localities, and Pearson $X^{2}=23.7,2$ d.f., $p<0.0001$ for states). The same was true when comparing our two study ecoregions, with significantly higher palm infestation rates in the Caatinga than in the Cerrado (80.3\% vs. 50.5\%; Pearson $X^{2}=20.3,1$ d.f., $p<0.0001$ ). A. speciosa was the palm species most frequently infested $(86.4 \%)$, followed by Mauritia flexuosa (84\%) (Table 3). These two palm species were common in at least some parts of all our study sites, and were infested by $R$. neglectus (in Cerrado localities) and $R$. nasutus (within the Caatinga ecoregion); Syagrus oleracea did also harbour both triatomine species, but was absent from our survey locality in Tocantins. Infestation rates were highest in palms of the Chapada do Araripe (86\%), and lowest in Jaraguá (38.5\%). This trend was reflected in the summary infestation rates by state, which were sig- nificantly higher in Ceará (80.3\%) than in Tocantins (44\%) or Goiás (56.6\%).

$R$. neglectus was frequently found in A. speciosa and M. flexuosa, with an infestation rate of $82.5 \%$ in both palm species. The density of $R$. neglectus colonies seems to be higher in Ac. aculeata and A. speciosa palms (with an average of 13 and 10.8 bugs/infested palm, respectively) than in other palm species, but may also be close to 7 bugs/infested palm in M. flexuosa (Table 4; see also Gurgel-Gonçalves et al., 2004a). All these palm species have wide geographical ranges in Brazil, and are commonly found in anthropic landscapes. Both A. speciosa and M. flexuosa were, however, absent from our sampling area in the municipality of Jaraguá, where $R$. neglectus has been found infesting houses and the landscape in characterised by extensive deforestation. In fact, only three large palm species were seen in Jaraguá, whereas five of them were common in Ponte Alta (where the bugs are still strictly sylvatic) and four were identified in Montes Claros (where peridomestic infestation is not rare). These observations suggest that deforestation reduces the diversity of palm tree habitats available to the bugs and their vertebrate hosts, thereby increasing the probability of dispersing adult bugs reaching households. Palms tended to be closer to households in Jaraguá than in either Ponte Alta or Montes Claros (mean distances $<350,>420$, and $>760 \mathrm{~m}$, respectively), a fact that could ease household invasion. Finally, the rates of natural infection by $T$. cruzi were also higher in Jaraguá (about 6\%), but infected bugs were found in all three survey localities and in all but one palm species (Table 5). Infection by $T$. rangeli was only detected in bugs from $M$. flexuosa palms collected in Ponte Alta (Diotaiuti et al., 1992).

The results of precipitin tests agree with the view that $R$. neglectus is mainly ornithophilic but may also feed on mammals (Table 6). The fact that a large proportion of samples did not react against our limited (see above) antisera battery (up to $>80 \%$ in Ponte Alta) suggests that these bugs may be much more eclectic in their feeding tastes than previously thought. The high fraction of non-reactive

Table 4

Rhodnius neglectus in palm trees of the Brazilian Cerrado: World Health Organisation density and crowding indices.

\begin{tabular}{|c|c|c|c|c|c|c|c|}
\hline \multirow[t]{2}{*}{ Palm species } & \multicolumn{2}{|c|}{ Number of palms } & \multicolumn{3}{|c|}{ Number of bugs } & \multicolumn{2}{|c|}{ WHO entomological indices ${ }^{a}$} \\
\hline & Surveyed & Infested & Adult & Nymph & Total & Density & Crowding \\
\hline Attalea speciosa & 40 & 33 & 138 & 219 & 357 & 8.93 & 10.82 \\
\hline Attalea phalerata & 49 & 13 & 10 & 38 & 48 & 0.98 & 3.69 \\
\hline Oenocarpus distichus & 20 & 1 & 1 & 0 & 1 & 0.05 & 1 \\
\hline Acrocomia aculeata & 47 & 22 & 145 & 141 & 286 & 6.09 & 13 \\
\hline Syagrus oleracea & 10 & 2 & 1 & 10 & 11 & 1.1 & 5.5 \\
\hline Mauritia flexuosa & 40 & 33 & 90 & 139 & 229 & 5.73 & 6.94 \\
\hline Total & 206 & 104 & 385 & 547 & 932 & 4.52 & 8.96 \\
\hline
\end{tabular}

a Density = number of bugs collected/number of palms surveyed; crowding = number of bugs collected/number of infested palms 
Table 5

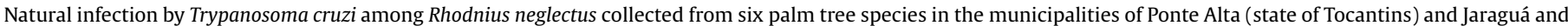
Montes Claros (state of Goiás), Brazil.

\begin{tabular}{|c|c|c|c|c|c|c|c|c|}
\hline \multirow{3}{*}{$\begin{array}{l}\text { Palm species } \\
\text { Acrocomia aculeata }\end{array}$} & \multicolumn{6}{|c|}{ Bugs examined and Natural Infection Index ${ }^{a}$} & \multirow{2}{*}{\multicolumn{2}{|c|}{ Total }} \\
\hline & \multicolumn{2}{|c|}{ Ponte Alta } & \multicolumn{2}{|c|}{ Jaraguá } & \multicolumn{2}{|c|}{ Montes Claros } & & \\
\hline & 83 & 0 & 47 & 2.1 & 156 & 1.3 & 286 & 1.05 \\
\hline Attalea speciosa & 145 & 1.4 & 0 & - & 212 & 3.3 & 357 & 2.52 \\
\hline Attalea phalerata & 0 & - & 10 & 20 & 38 & 0 & 48 & 4.17 \\
\hline Syagrus oleracea & 0 & - & 11 & 9.1 & 0 & - & 11 & 9.09 \\
\hline Mauritia flexuosa & 150 & 2 & 0 & - & 79 & 0 & 229 & 1.31 \\
\hline Oenocarpus distichus & 1 & 0 & 0 & - & 0 & - & 1 & 0 \\
\hline Total & 378 & 1.3 & 68 & 5.9 & 485 & 1.9 & 932 & 1.93 \\
\hline
\end{tabular}

a Natural Infection Index = percentage of bugs in which infection by Trypanosoma cruzi was detected.

Table 6

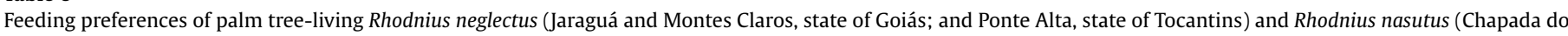
Araripe, state of Ceará): results of precipitin reaction tests; all samples tested negative against human, dog, rodent, pig, and lizard antisera.

\begin{tabular}{|c|c|c|c|c|c|c|c|}
\hline \multirow[t]{2}{*}{ Species and locality } & \multirow[t]{2}{*}{ Stage } & \multicolumn{4}{|c|}{ Antisera and \% reactive samples } & \multirow{2}{*}{$\begin{array}{l}\text { Non-reactive } \\
\text { samples (\%) }\end{array}$} & \multirow{2}{*}{$\begin{array}{l}\text { Number of samples } \\
\text { examined }\end{array}$} \\
\hline & & Bird & Cat & Bat & Opossum & & \\
\hline \multirow[t]{3}{*}{ Rhodnius neglectus Jaraguá } & Adult & 31.25 & 0 & 0 & 0 & 68.75 & 16 \\
\hline & Nymph & 34.48 & 0 & 0 & 3.45 & 62.07 & 29 \\
\hline & Total & 33.33 & 0 & 0 & 2.22 & 64.44 & 45 \\
\hline \multirow[t]{3}{*}{ Rhodnius neglectus Montes Claros } & Adult & 56.78 & 0.85 & 1.69 & 0 & 40.68 & 118 \\
\hline & Nymph & 71.43 & 0 & 0 & 0 & 28.57 & 7 \\
\hline & Total & 57.60 & 0.8 & 1.6 & 0 & 40 & 125 \\
\hline \multirow[t]{3}{*}{ Rhodnius neglectus Ponte Alta } & Adult & 9.38 & 0 & 0 & 0 & 90.63 & 32 \\
\hline & Nymph & 29.63 & 0 & 0 & 0 & 70.37 & 27 \\
\hline & Total & 18.64 & 0 & 0 & 0 & 81.36 & 59 \\
\hline \multirow[t]{3}{*}{ Rhodnius neglectus (total) } & Adult & 45.18 & 0.60 & 1.20 & 0 & 53.01 & 166 \\
\hline & Nymph & 36.51 & 0 & 0 & 1.59 & 61.90 & 63 \\
\hline & Total & 42.79 & 0.44 & 0.87 & 0.44 & 55.46 & 229 \\
\hline \multirow[t]{3}{*}{ Rhodnius nasutus Chapada do Araripe } & Adult & 15.2 & 0 & $\mathrm{Nt}$ & 37 & 48.9 & $30^{a}$ \\
\hline & Nymph & 20 & 0 & $\mathrm{Nt}$ & 63.3 & 23.3 & $92^{\mathrm{a}}$ \\
\hline & Total & 16.4 & 0 & $\mathrm{Nt}$ & 43.4 & 42.6 & 122 \\
\hline
\end{tabular}

$\mathrm{Nt}=$ not tested.

a Three R. nasutus specimens (two nymphs and one adult) tested positive for both bird and opossum blood.

samples in Ponte Alta seems to parallel the locally higher diversity of palms, which might perhaps provide shelter to a more diverse vertebrate fauna.

Natural infection by T. cruzi was more frequent in R. nasutus than in $R$. neglectus. Almost $17 \%$ of $R$. nasutus from the Chapada do Araripe were infected, with a maximum rate of $21.5 \%$ in bugs collected in A. speciosa palms (Table 7). These triatomines appeared to be only partially ornithophilic, with a high proportion of samples reacting against opossum antisera $(>43 \%)$ in precipitin tests; a similar number of samples $(42.6 \%)$ did not react against our antisera battery (Table 6). A detailed comparison of phenotypic traits revealed striking chromatic and size-related variation in $R$. nasutus collected from either A. speciosa or C. prunifera palms in Ceará. While the latter match the original description by Stål (small, brown-reddish

Table 7

Natural infection by Trypanosoma cruzi among Rhodnius nasutus collected from five palm tree species in the Chapada do Araripe (state of Ceará), Brazil.

\begin{tabular}{lccc}
\hline Palm species & \multicolumn{2}{c}{ Bugs } & NII $^{\mathrm{a}}$ \\
\cline { 2 - 3 } & Examined & Infected & \\
\hline Attalea speciosa & 144 & 31 & 21.5 \\
Mauritia flexuosa & 15 & 1 & 6.7 \\
Copernicia prunifera & 16 & 0 & 0 \\
Syagrus oleracea & 148 & 29 & 19.6 \\
Acrocomia intumescens & 59 & 3 & 5.1 \\
Total & 382 & 64 & 16.8 \\
\hline
\end{tabular}

a NII, Natural Infection Index (percentage of bugs in which infection by Trypanosoma cruzi was detected). bugs), the former tend to be larger on average (but with similar overall head and wing shape) and markedly darker (Diotaiuti et al., 2005; Dias, 2007). Both chromatic and size variation in the absence of shape divergence may be explained by adaptive phenotypic plasticity related to microhabitat features, with the fixation of substrate-matching hues (light-reddish in Copernicia and darkbrown in Attalea) driven by predation pressure and size variation by palm crown microclimate (drier-hotter in Copernicia than in Attalea) (Gaunt and Miles, 2000; Abad-Franch et al., 2003a; Lorenzo et al., 2003).

\subsubsection{Conclusions}

Taken as a whole, the results of our mesoscale ecological survey suggest the following:

(1) $R$. neglectus is an ecologically versatile species capable of exploiting diverse palm tree habitats and vertebrate hosts (preferentially birds) in the wild.

(2) R. nasutus is more eclectic and ecologically diverse than previously thought. It was only known to occur in C. prunifera and A. speciosa, but we detected infestation of three further palm species: Ac. intumescens, M. flexuosa, and S. oleracea; unpublished observations (LD) indicate that it can also infest the nests of furnariid birds built on trees in the Caatinga. We also confirmed that this species is common in the humid premontane formations that punctuate the semi-arid Caatinga in northeastern Brazil. $R$. nasutus palm populations exploit both avian and 
mammalian blood sources. Finally, our data suggest that microhabitat adaptations probably underlie phenotypic diversity in $R$. nasutus, with chromatic and size variants associated with different palm species.

(3) The patterns of palm tree infestation by sylvatic populations of $R$. neglectus and $R$. nasutus are heterogeneous at the landscape scale; in our sample, palm infestation rates were higher in the state of Ceará, intermediate in Goiás, and lower in Tocantins. Palm trees were significantly more likely to harbour sylvatic Rhodnius breeding colonies in the Caatinga than in the Cerrado.

(4) Species-specific palm traits also seem to modulate the likelihood of infestation; architectural complexity, microclimate traits, and host abundance/diversity are all possible (and very probably not mutually exclusive) causes (Romaña et al., 1999; Lorenzo et al., 2003; Abad-Franch et al., 2005).

(5) Finally, deforestation and habitat loss may result in a higher likelihood of contact between infected $R$. neglectus and humans in central Brazil; vector surveillance efforts should, therefore, concentrate in heavily deforested areas (rural or peri-urban) where large palms are common near households. These dynamics may very well not be restricted to our survey sites and our target palm and triatomine species; other palms and other Rhodnius species are probably subject to similar ecological stressors in other subregions of Latin America, and may be responding in similar ways.

\section{Final considerations}

Integrating different spatial scales into a comprehensive framework represents a major challenge in ecological research (Levin, 1992; Leibold et al., 2004). It entails the recognition that many, highly diverse factors and processes contribute to shape the patterns of biological diversity, and that, as S.A. Levin (1992; abstract) put it, "there is no single natural scale at which ecological phenomena should be studied". However modest, our present contribution to this undertaking consists in highlighting the importance of explicitly considering different spatial scales in infectious disease ecology research. Each of these scales calls for specific questions, and this translates into such crucial methodological issues as the formulation of hypotheses, the deduction of predictions, the choice of variables to be measured, the design of sampling strategies, the analytical treatment of the data, and the extension and depth of the derived inferences and interpretations. In other words, we stress the fact that ecological dynamics are strongly dependent on the scale at which the phenomena of interest are considered, and that a coherent view of those phenomena can only be derived from the understanding of multi-scale patterns (Levin, 1992).

In practical terms, we suggest that the development of epidemiological risk management tools is also scale-dependent. First, both macro- and mesoscale eco-epidemiological knowledge can be used for spatially explicit disease transmission risk modelling; the derived risk maps may help optimise resource allocation for disease control-surveillance. Second, the identification of mesoscale (landscape) factors that can result in higher likelihood of contact between infected vectors and susceptible humans (e.g., biodiversity loss, species-specific palm traits, and demographic or behavioural shifts in vectors or reservoirs) can guide the design of site-specific surveillance systems and, perhaps, also of environmental management strategies to aid vector control (Abad-Franch et al., 2005). Finally, evidence-based eco-epidemiological wisdom can stimulate (and perhaps orient) the debate over the need for development policies that acknowledge the predictable effects of anthropic environmental transformations on public health. We anticipate that, by helping define the distribution patterns and ecological prefer- ences of each vector species, multi-scale research will significantly strengthen disease control-surveillance systems across Latin America.

\section{Acknowledgements}

Different parts of this work were funded by the UNICEF/UNDP/ World Bank/WHO TDR Special Programme (ID\#A20441), the agreements Fiocruz-CNPq and Fiocruz-FAPEAM, FAP-DF, FAPEMIG, CNPq, and the CPqRR. This work also benefited from international collaboration through the ECLAT Network. FA-F's contribution to this work derives from the activities of the Research Programme on Infectious Disease Ecology in the Amazon (RP-IDEA) of the Instituto Leônidas \& Maria Deane; this paper is, in this sense, publication number 5 of the RP-IDEA.

\section{References}

Abad-Franch, F., Monteiro, F.A., 2005. Molecular research and the control of Chagas disease vectors. An. Acad. Bras. Ciências 77, 437-454.

Abad-Franch, F., Monteiro, F.A., 2007. Biogeography and evolution of Amazonian triatomines (Heteroptera: Reduviidae): implications for Chagas disease surveillance in humid forest ecoregions. Mem. Inst. Oswaldo Cruz 102 (Suppl. 1), 57-69.

Abad-Franch, F., Monteiro, F.A., Aguilar, H.M., Miles, M.A., 2004. Population-level mitochondrial DNA sequence diversity in Rhodnius ecuadoriensis. In: Programme and abstracts, IX European Multicolloquium of Parasitology, Valencia, Spain, July 2004, p. 201.

Abad-Franch, F., Monteiro, F.A., Patterson, J.S., Aguilar, H.M., Beard, C.B., Miles, M.A., 2003a. Population phenotypic plasticity linked to ecological adaptations in Triatominae. Rev. Inst. Med. Trop. São Paulo 45 (Suppl. 13), 199-200.

Abad-Franch, F., Monteiro, F.A., Patterson, J.S., Miles, M.A., 2003b. Phylogenetic relationships among members of the Pacific Rhodnius lineage (Hemiptera: Reduviidae: Triatominae). Infect. Genet. Evol. 2, 244-245.

Abad-Franch, F., Palomeque, F.S., Aguilar, V.H.M., Miles, M.A., 2005. Field ecology of sylvatic Rhodnius populations (Heteroptera, Triatominae): risk factors for palm tree infestation in western Ecuador. Trop. Med. Int. Health 10, 1258-1266.

Abad-Franch, F., Paucar, C.A., Carpio, C.C., Cuba Cuba, C.A., Aguilar, V.H.M., Miles, M.A., 2001. Biogeography of Triatominae (Hemiptera: Reduviidae) in Ecuador: implications for the design of control strategies. Mem. Inst. Oswaldo Cruz 96, 611-620.

Ab'Sáber, A.N., 1977. Os domínios morfoclimáticos na América do Sul. Primeira aproximação. Geomorfologia 52, 1-21.

Aguilar, H.M., Abad-Franch, F., Dias, J.C.P., Junqueira, A.C.V., Coura, J.R., 2007. Chagas disease in the Amazon region. Mem. Inst. Oswaldo Cruz 102 (Suppl. 1), 47-55.

Aldana, E., Lizano, E., Valderrama, A., 2003. Revisión del estatus taxonómico de Rhodnius pictipes Stål 1872 (Hemiptera, Reduviidae, Triatominae). Bol. Malariol. Salud Amb. 43, 31-38.

Aleixo, A., 2004. Historical diversification of a "terra-firme" forest bird superspecies: a phylogeographic perspective on the role of different hypotheses of Amazonian diversification. Evolution 58, 1303-1317.

Aleixo, A., Rosetti, D.F., 2007. Avian gene trees, landscape evolution, and geology: towards a modern synthesis of Amazonian historical biogeography? J. Ornithol. 148 (Suppl. 2), S443-S453.

Alencar, J.E. 1987. História natural da doença de Chagas no Ceará. Imprensa Universitária, Universidade Federal do Ceará, Fortaleza, 341 pp.

Anonymous, 2007. Workshop on epidemiology and social determining factors of Chagas disease. Basic information for surveillance and control policy in Latin America. Introduction, regional context, precedings, and recommendations. Mem. Inst. Oswaldo Cruz 102 (Suppl. 1), 5-10.

Asmussen, C.B., Dransfield, J., Deickmann, V., Barfod, A.S., Pintaud, J.C., Baker, W.J., 2006. A new subfamily classification of the palm family (Arecaceae): evidence from plastid DNA phylogeny. Bot. J. Linn. Soc. 151, 15-38.

Avise, J.C., Walker, D., 1999. Species realities and numbers in sexual vertebrates: Perspectives from an asexually transmitted genome. Proc. Natl. Acad. Sci. U.S.A. 96, 992-995.

Barrett, T.V., 1991. Advances in triatomine bug ecology in relation to Chagas disease. Adv. Dis. Vector Res. 8, 143-176.

Barrett, T.V., 1996. Species interfertility and crossing experiments in triatomine systematics. In: Schofield, C.J., Dujardin, J.P., Jurberg, J. (Eds.), Proceedings of the International Workshop on population genetics and control of Triatominae. Santo Domingo de los Colorados, Ecuador, September 1995. INDRE, Mexico City, pp. $72-77$.

Barretto, M.P., 1976. Ecologia de triatomíneos e transmissão do Trypanosoma cruzi, com especial referência ao Brasil. Rev. Soc. Bras. Med. Trop. 10, 339-353.

Barretto, M.P. 1979. Epidemiologia. In: Z. Brener and Z. Andrade (Eds.) Trypanosoma cruzi e doença de Chagas. Guanabara Koogan, Rio de Janeiro, pp. 89-151.

Barretto, M.P., Siqueira, A.F., Ferriolli, F.F., Carvalheiro, J.R., 1968. Estudos sobre reservatórios e vetores do Trypanosoma cruzi. XXIII. Observações sobre criadouros do 
Rhodnius neglectus Lent, 1954 em biótopos artificiais (Hemiptera, Reduviidae). Rev. Inst. Med. Trop. São Paulo 10, 163-170.

Bjorholm, S., Svenning, J.C., Baker, W.J., Skov, F., Balslev, H., 2006. Historical legacies in the geographical diversity patterns of new world palm (Arecaceae) subfamilies. Bot. J. Linn. Soc. 151, 113-125.

Bjorholm, S., Svenning, J.C., Skov, F., Balslev, H., 2005. Environmental and spatial controls of palm (Arecaceae) species richness across the Americas. Global Ecol. Biogeogr. 14, 423-429.

Blaxter, M., Mann, J., Chapman, T., Thomas, F., Whitton, C., Floyd, R., Abebe, E., 2005. Defining operational taxonomic units using DNA barcode data. Philos. Trans. R. Soc. Lond. B Biol. Sci. 360, 1935-1943.

Bookstein, F.L., 1991. Morphometric Tools for Landmark Data: Geometry and Biology. Cambridge University Press, Cambridge, xvii +435 pp.

Carcavallo, R.U., Galíndez-Girón, I., Jurberg, J., Lent, H. (Eds.) 1999. Atlas of Chagas disease vectors in the Americas, Vol. III. Editora Fiocruz, Rio de Janeiro, 393 pp.

Carcavallo, R.U., Martínez, A. 1985. Biología, ecología y distribución geográfica de los triatominos americanos. In: R.U. Carcavallo, J.E. Rabinovich and R.J.Tonn (Eds.), Factores biológicos y ecológicos en la enfermedad de Chagas, Vol. II. Centro Panamericano de Ecología Humana y Salud OPS/OMS - Servicio Nacional de Chagas, Ministerio de Salud y Acción Social, Buenos Aires, pp. 149-208.

Chagas, C.R.J., 1909. Nova Trypanozomiaze humana. Estudos sobre a morfologia e o ciclo evolutivo do Schizotrypanum cruzi n. gen., n. sp., ajente etiologico de nova entidade morbida no homem. Mem. Inst. Oswaldo Cruz 1, 159-218.

Chávez, J., 2006. Contribución al estudio de los triatominos del Perú: distribución geográfica, nomenclatura y notas taxonómicas. An. Fac. Med. Lima 67, 65-76.

Condit, R., Pitman, N., Leigh Jr., E.G., Chave, J., Terborgh, J., Foster, R.B., Núñez, P., Aguilar, S., Valencia, R., Villa, G., Muller-Landau, H.C., Losos, E., Hubbell, S.P., 2002. Beta-diversity in tropical forest trees. Science 295, 666-669.

Conn, J.E., Mirabello, L., 2007. The biogeography and population genetics of Neotropical vector species. Heredity 99, 245-256.

Correa, R.R., 1968. Informe sobre a doença de Chagas no Brasil, e em especial no Estado de São Paulo. Rev. Bras. Malariol. Doenças Trop. 20, 39-81.

Costa, L.P., 2003. The historical bridge between the Amazon and the Atlantic Forest of Brazil: a study of molecular phylogeography with small mammals. J. Biogeogr. 30, 71-86.

Coura, J.R., 2007. Chagas disease: what is known and what is needed-a background article. Mem. Inst. Oswaldo Cruz 102 (Suppl. 1), 113-122.

Coura, J.R., Junqueira, A.C.V., Fernandes, O., Valente, S.A.S., Miles, M.A., 2002. Emerging Chagas disease in Amazonian Brazil. Trends Parasitol. 18, 171-176.

Cox, C.B., Moore, P.D., 2000. Biogeography. An Ecological and Evolutionary Approach. Blackwell Science, Oxford, 298 pp.

Cuba Cuba, C.A., Abad-Franch, F., Roldán, R.J., Vargas, V.F., Pollack, V.L., Miles, M.A., 2002. The triatomines of northern Peru, with emphasis on the ecology and infection by trypanosomes of Rhodnius ecuadoriensis (Triatominae). Mem. Inst. Oswaldo Cruz 97, 175-183.

de Paula, A.S., Diotaiuti, L., Galvão, C., 2007. Systematics and biogeography of Rhodniini (Heteroptera: Reduviidae: Triatominae) based on 16S mitochondrial rDNA sequences. J. Biogeogr. 34, 699-712.

Dias, F.B.S. 2007. Ecologia de Rhodnius nasutus Stål, 1859 (Hemiptera: Reduviidae: Triatominae) em palmeiras da Chapada do Araripe, Ceará, Brasil. MSc. Thesis, Centro de Pesquisas René Rachou, Fiocruz, Belo Horizonte, 121 pp.

Dias, J.C.P. 2002. O controle da doença de Chagas no Brasil. In: A.C. Silveira (Ed.) El control de la enfermedad de Chagas en los países del Cono Sur de América. Historia de una iniciativa internacional. 1991/2001. Faculdade de Medicina do Triângulo Mineiro-Pan American Health Organization, Uberaba, pp. 145-250.

Dias, J.C.P., Machado, E.M.M., Fernandes, A.L., Vinhaes, M.C., 2000. Esboço geral e perspectivas da doença de Chagas no Nordeste do Brasil. Cad. Saúde Públ. 16 (Suppl. II), 13-34.

Diotaiuti, L., Dias, J.C.P., 1984. Ocorrência e biologia do Rhodnius neglectus Lent, 1954 em macaubeiras da periferia de Belo Horizonte-MG. Mem. Inst. Oswaldo Cruz 79, 293-301.

Diotaiuti, L., Lorenzo, M.G., Dias, F.B.S., Bezerra, C.M., Garcia, M.H., Paula, A.S., 2005. Influência da espécie de palmeira sobre o tamanho de Rhodnius nasutus (Stål 1859) provenientes de carnaúbas ou babaçus do Ceará, Brasil. Rev. Soc. Bras. Med. Trop. 38 (Suppl. 1), 44.

Diotaiuti, L., Silveira, A.C., Elias, M., Steindel, M., 1992. The possibility of occurrence of Trypanosoma rangeli in the state of Tocantins, Brazil. Mem. Inst. Oswaldo Cruz $87,451$.

dos Santos, S.M., Lopes, C.M., Dujardin, J.P., Panzera, F., Pérez, R., Carbajal de la Fuente, A.L., Pacheco, R.S., Noireau, F., 2007. Evolutionary relationships based on genetic and phenetic characters between Triatoma maculata, Triatoma pseudomaculata and morphologically related species (Reduviidae: Triatominae). Infect. Genet. Evol. 7, 469-475

Dujardin, J.P., Beard, C.B., Ryckman, R., 2007. The relevance of wing geometry in entomological surveillance of Triatominae, vectors of Chagas disease. Infect. Genet. Evol. 7, 161-167.

Dujardin, J.P., Muñoz, M., Chávez, T., Ponce, C., Moreno, J., 1998. The origin of Rhodnius prolixus in Central America. Med. Vet. Entomol. 12, 113-115.

Dujardin, J.P., Panzera, F., Schofield, C.J., 1999. Triatominae as a model of morphological plasticity under ecological pressure. Mem. Inst. Oswaldo Cruz 94 (Suppl. 1), 223-228.

Feliciangeli, M.D., Sánchez-Martín, M., Marrero, R., Davies, C., Dujardin, J.P., 2007. Morphometric evidence for a possible role of Rhodnius prolixus from palm trees in house re-infestation in the State of Barinas (Venezuela). Acta Trop. 101, 169-177.
Forattini, O.P., 1980. Biogeografia, origem e distribuição da domiciliação de triatomíneos no Brasil. Rev. Saúde Públ. 14, 265-299.

Forattini, O.P., Barata, J.M.S., Santos, J.L.F., Silveira, A.C., 1981. Hábitos alimentares, infecção natural e distribuição de triatomíneos domiciliados na região Nordeste do Brasil. Rev. Saúde Públ. 15, 113-164.

Galvão, C., Rocha, D.S., Carcavallo, R.U., Jurberg, J., 2003. A checklist of the current valid species of the subfamily Triatominae Jeannel, 1919 (Hemiptera, Reduviidae) and their geographical distribution, with nomenclatural and taxonomic notes. Zootaxa 202, 1-36.

Garzón-Orduña, I.J., Miranda-Esquivel, D.F., Donato, M., 2007. Parsimony analysis of endemicity describes but does not explain: an illustrated critique. J. Biogeogr. 35, 903-913, doi:10.1111/j.1365-2699.2007.01842.x.

Gaunt, M.W., Miles, M.A., 2000. The ecotopes and evolution of triatomine bugs (Triatominae) and their associated trypanosomes. Mem. Inst. Oswaldo Cruz 95 557-565.

Gaunt, M.W., Miles, M.A., 2002. An insect molecular clock dates the origin of the insects and accords with palaeontological and biogeographic landmarks. Mol Biol. Evol. 19, 748-761.

Gotelli, N.J., Colwell, R.K., 2001. Quantifying biodiversity: procedures and pitfalls in the measurement and comparison of species richness. Ecol. Lett. 4, 379-391.

Gregory-Wodzicki, K.M., 2000. Uplift history of the central and northern Andes: a review. GSA Bull. 112, 1091-1105.

Grijalva, M.J., Palomeque-Rodríguez, F.S., Costales, J.A., Dávila, S., Arcos-Terán, L., 2005. High household infestation rates by synanthropic vectors of Chagas disease in southern Ecuador. J. Med. Entomol. 42, 68-74.

Guhl, F., Aguilera, G., Pinto, N., Vergara, D., 2007. Updated geographical distribution and ecoepidemiology of the triatomine fauna (Reduviidae: Triatominae) in Colombia. Biomédica 27 (Suppl. 1), 143-162.

Guilherme, A.L., Pavanelli, G.C., Silva, S.V., Costa, A.L., de Araújo, S.M., 2001. Secondary triatomine species in dwellings and other nearby structures in municipalities under epidemiological surveillance in the state of Paraná, Brazil. Rev. Panam. Salud Públ. 9, 385-392.

Gumiel, M., Catalá, S., Noireau, F., Rojas de Arias, A., García, A., Dujardin, J.P., 2003 Wing geometry in Triatoma infestans (Klug) and T. melanosoma Martínez, Olmedo and Carcavallo (Hemiptera, Reduviidae). Syst. Entomol. 28, 173-179.

Gurgel-Gonçalves, R., Abad-Franch, F., Ferreira, J.B.C., Santana, D.B., Cuba, C.A.C. 2008. Is Rhodnius prolixus (Triatominae) invading houses in Central Brazil? Acta Trop. 107, 90-98.

Gurgel-Gonçalves, R., Duarte, M.A., Ramalho, E.D., Romaña, C.A., Cuba, C.A.C., 2004a Distribuição espacial de populações de Triatominae (Hemiptera, Reduviidae) em palmeiras da espécie Mauritia flexuosa no Distrito Federal, Brasil. Rev. Soc. Bras. Med. Trop. 37, 241-247.

Gurgel-Gonçalves, R., Palma, A.R.T., Menezes, M.N.A., Leite, R.N., Cuba, C.A.C., 2003 Sampling Rhodnius neglectus (Triatominae) in Mauritia flexuosa palm trees (Arecaceae): a field study in the Brazilian Savanna. Med. Vet. Entomol. 17, 347-349.

Gurgel-Gonçalves, R., Ramalho, E.D., Duarte, M.A., Palma, A.R.T., Abad-Franch, F., Carranza, J.C., Cuba, C.A.C., 2004b. Enzootic transmission of Trypanosoma cruzi and T. rangeli in the Federal District of Brazil. Rev. Inst. Med. Trop. São Paulo 46, 323-330.

Haffer J. 1969. Speciation in Amazonian forest birds. Science 165, 131-137.

Haffer, J., 1997. Alternative models of vertebrate speciation in Amazonia: an overview. Biodiv. Conserv. 6, 451-476.

Harry, M., 1993. Use of the median process of the pygophore in the identification of Rhodnius nasutus, $R$. neglectus, $R$. prolixus and $R$. robustus (Hemiptera: Reduviidae). Ann. Trop. Med. Parasitol. 87, 277-282.

Hebert, P.D.N., Cywinska, A., Ball, S.L., de Waard, J.R., 2003a. Biological identifications through DNA barcodes. Proc. R. Soc. Lond. B 270, 313-321.

Hebert, P.D.N., Ratnasingham, S., de Waard, J.R., 2003b. Barcoding animal life: cytochrome $c$ oxidase subunit 1 divergences among closely related species. Proc. R. Soc. Lond. B 270 (Suppl.), S96-S99.

Hebert, P.D.N., Stoeckle, M.Y., Zemlak, T.S., Francis, C.M., 2004. Identification of birds through DNA barcodes. PLoS Biol. 2, 1657-1663.

Henderson, A.J., Galeano, G., Bernal, R., 1995. Field Guide to the Palms of the Americas. Princeton University Press, Princeton, NJ, 352 pp.

Hooghiemstra, H., Van Der Hammen, T., 1998. Neogene and Quaternary development of the Neotropical rain forest: the forest refugia hypothesis, and a literature overview. Earth Sc. Rev. 44, 147-183.

Irestedt, M., Fjeldså, J., Ericson, P.G.P., 2006. Evolution of the ovenbird-woodcreeper assemblage (Aves: Furnariidae)-major shifts in nest architecture and adaptive radiation. J. Avian Biol. 37, 260-272.

Kahn, F. 1990. Clave para diferenciar los géneros de Palmae em la Amazonia a partir del aparato vegetativo, complementada por uma breve descripción de los géneros, la distribución geográfica y ecológica, y los nombres vernáculos más comunes. Bull. Inst. Fr. Études Andines 19, 351-378.

Kumar, S., Tamura, K., Nei, M., 2004. MEGA3: integrated software for molecular evolutionary genetics analysis and sequence alignment. Brief. Bioinform. 5, $150-163$.

Landis, J.R., Koch, G.G., 1977. The measurement of observer agreement for categorical data. Biometrics 33, 159-174.

Leibold, M.A., Holyoak, M., Mouquet, N., Amarasekare, P., Chase, J.M., Hoopes, M.F. Holt, R.D., Shurin, J.B., Law, R., Tilman, D., Loreau, M., González, A., 2004. The metacommunity concept: a framework for multi-scale community ecology. Ecol. Lett. 7, 601-613.

Lent, H., 1954. Comentários sobre o gênero Rhodnius Stål com descrição de uma nova espécie do Brasil (Hemiptera, Reduviidae). Rev. Bras. Biol. 14, 237-247. 
Lent, H., Wygodzinsky, P., 1979. Revision of the Triatominae (Hemiptera, Reduviidae), and their significance as vectors of Chagas' disease. Bull. Am. Mus. Nat. Hist. 163, 520-529.

Levin, S.A., 1992. The problem of pattern and scale in ecology. Ecology 76, 1943-1967.

Lorenzi, H., Souza, H.M., Medeiros-Costa, J.T., Cerqueira, L.S.C., Behr, N. 1996 Palmeiras no Brasil, nativas e exóticas. Plantarum, Nova Odessa, São Paulo, 303 pp.

Lorenzo, M.G., Minoli, A.S., Lazzari, C.R., Paula, A.S., Diotaiuti, L., 2003. O microclima dos ecótopos naturais das espécies do gênero Rhodnius no município de Tocantinópolis, estado de Tocantins, Brasil. Rev. Soc. Bras. Med. Trop. 36 (Suppl. 1), 425.

Lucena, D.T., Lima-Borba, H., 1977. Panstrongylus megistus leucofasciatus Lucena, 1959 e Rhodnius nasutus Stål, 1859 (Hemiptera: Triatominae) em Pernambuco, Brasil. Rev. Inst. Med. Trop. São Paulo 19, 332-334.

Martins, A.V., Versiani, V., Tupinambá, A.A., 1940. Estudos sobre a tripanosomíase Americana em Minas Gerais, Brasil. Mem. Inst. Oswaldo Cruz 35, 285-301.

Mathers, C.D., Lopez, A.D., Murray, C.J.L., 2006. The burden of disease and mortality by condition: data, methods, and results for 2001. In: Lopez, A.D., Mathers, C.D. Ezzati, M., Murray, C.J.L., Jamison, D.T. (Eds.), Global Burden of Disease and Risk Factors. Oxford University Press-World Bank, New York, NY, pp. 45-234.

Matías, A., De La Riva, J., Martínez, E., Torrez, M., Dujardin, J.P., 2003. Domiciliation process of Rhodnius stali (Hemiptera: Reduviidae) in Alto Beni, La Paz. Bolivia. Trop. Med. Int. Health 8, 264-268.

Matías, A., De la Riva, J., Torrez, M., Dujardin, J.P., 2001. Rhodnius robustus in Bolivia identified by its wings. Mem. Inst. Oswaldo Cruz 96, 947-950.

Miles, M.A., Feliciangeli, M.D., Rojas de Arias, A., 2003. Science, medicine, and the future: American trypanosomiasis (Chagas' disease) and the role of molecular epidemiology in guiding control strategies. BMJ 326, 1444-1448.

Miller, S.E., 2007. DNA barcoding and the renaissance of taxonomy. Proc. Natl. Acad. Sci. U.S.A. $104,4775-4776$.

Mittermeier, R.A., Mittermeier, C.G., Brooks, T.M., Pilgrim, J.D., Konstant, W.R., da Fonseca, G.A.B., Kormos, C., 2003. Wilderness and biodiversity conservation. Proc. Natl. Acad. Sci. U.S.A. 100, 10309-10313.

Monteiro, F.A., Barrett, T.V., Fitzpatrick, S., Cordón-Rosales, C., Feliciangeli, M.D., Beard, C.B., 2003. Molecular phylogeography of the Amazonian Chagas disease vectors Rhodnius prolixus and $R$. robustus. Mol. Ecol. 12, 997-1006.

Monteiro, F.A., Escalante, A.A., Beard, C.B., 2001. Molecular tools and triatomine systematics: a public health perspective. Trends Parasitol. 17, 344-347.

Monteiro, F., Wesson, D.M., Dotson, E.M., Schofield, C.J., Beard, C.B., 2000. Phylogeny and molecular taxonomy of the Rhodniini derived from mitochondrial and nuclear DNA sequences. Am. J. Trop. Med. Hyg. 62, 460-465.

Morel, C.M., Lazdins, J., 2003. Chagas disease. Nature Rev. Microbiol. 1, 14-15.

Morrone, J.J., 2006. Biogeographic areas and transition zones of Latin America and the Caribbean islands based on panbiogeographic and cladistic analyses of the entomofauna. Annu. Rev. Entomol. 51, 467-494.

Nores, M., 1999. An alternative hypothesis for the origin of Amazonian bird diversity. J. Biogeogr. 26, 475-485.

Nores, M., 2004. The implications of tertiary and quaternary sea level rise events for avian distribution patterns in the lowlands of northern South America. Global Ecol. Biogeogr. 13, 149-161.

Oliveira, A.W.S., Silva, I.G., 2007. Distribuição geográfica e indicadores entomológicos de triatomíneos sinantrópicos capturados no Estado de Goiás. Rev. Soc. Bras. Med. Trop. 40, 204-208.

Olson, D.M., Dinerstein, E., Wikramanayake, E.D., Burgess, N.D., Powell, G.V.N., Underwood, E.C., D’Amico, J.A., Itoua, I., Strand, H.E., Morrison, J.C., Loucks, C.J. Allnutt, T.F., Ricketts, T.H., Kura, Y., Lamoreux, J.F., Wettengel, W.W., Hedao, P., Kassem, K.R., 2001. Terrestrial Ecoregions of the World: a new map of life on Earth. Bioscience 51, 933-938.

Ostfeld, R.S., Glass, G.E., Keesing, F., 2005. Spatial epidemiology: an emerging (or re-emerging) discipline. Trends Ecol. Evol. 20, 328-336.

Pavan, M.G., Monteiro, F.A., 2007. A multiplex PCR assay that separates Rhodnius prolixus from members of the Rhodnius robustus cryptic species complex (Hemiptera: Reduviidae). Trop. Med. Int. Health 12, 751-758.

Pellegrino, J., 1950. Novos dados sobre a distribuição de triatomíneos e sua infecção pelo Schizotrypanum cruzi no estado de Minas Gerais (Brasil). Mem. Inst. Oswaldo Cruz 48, 639-667.

Pons, J., Barraclough, T.G., Gómez-Zurita, J., Cardoso, A., Durán, D.P., Hazell, S. Kamoun, S., Sumlin, W.D., Vogler, A.P., 2006. Sequence-based species delimitation for the DNA taxonomy of undescribed insects. Syst. Biol. 55, 595-609.

Porzecanski, A.L., Cracraft, J., 2005. Cladistic analysis of distributions and endemism (CADE): using raw distributions of birds to unravel the biogeography of the South American aridlands. J. Biogeogr. 32, 261-275

Quijada-Mascareñas, J.A., Ferguson, J.E., Pook, C.E., Salomão, M.D.G., Thorpe, R.S. Wüster, W., 2007. Phylogeographic patterns of trans-Amazonian vicariants and Amazonian biogeography: the Neotropical rattlesnake (Crotalus durissus complex) as an example. J. Biogeogr. 34, 1296-1312.
Racheli, L., Racheli, T., 2004. Patterns of Amazonian area relationships based on raw distributions of papilionid butterflies (Lepidoptera: Papilionidae). Biol. J. Linn. Soc. $82,345-357$.

Ratnasingham, S., Hebert, P.D.N. 2007. BOLD: the barcode of life data system (www.barcodinglife.org). Mol. Ecol. Notes 7, 355-364.

Ribas, C.C., Gaban-Lima, R., Miyaki, C.Y., Cracraft, J., 2005. Historical biogeography and diversification within the Neotropical parrot genus Pionopsitta (Aves: Psittacidae). J. Biogeogr. 32, 1409-1427.

Rogers, A.R., Harpending, H., 1992. Population growth makes waves in the distribution of pairwise genetic differences. Mol. Biol. Evol. 9, 552-569.

Rohlf, F.J., 1996. Morphometric spaces, shape components and the effects of linear transformations. In: Marcus, L.F., Corti, M., Loy, A., Naylor, G.J.P., Slice, D. (Eds.), Advances in Morphometrics. NATO ASI, Series A, Life Sciences. Plenum Publication, New York, NY, pp. 117-129.

Rohlf, F.J. 1999a. tpsDig, version 1.18. Department of Ecology and Evolution, State University of New York, Stony Brook, NY (http://life.bio.sunysb.edu/morph/).

Rohlf, F.J. 1999b. tpsRelw, version 1.18. Department of Ecology and Evolution, State University of New York, Stony Brook, NY (http://life.bio.sunysb.edu/morph/).

Romaña, C.A., Pizarro, J.C., Rodas, E., Guilbert, E., 1999. Palm trees as ecological indicators of risk areas for Chagas disease. Trans. R. Soc. Trop. Med. Hyg. 93, 594-595.

Ron, S.R., 2000. Biogeographic area relationships of lowland Neotropical rainforest based on raw distributions of vertebrate groups. Biol. J. Linn. Soc. 71, 379-402.

Rosen, B.R., 1988. From fossils to Earth history: applied historical biogeography. In: Myers, A.A., Giller, P.S. (Eds.), Analytical Biogeography: An Integrated Approach to the Study of Animal and Plant Distributions. Chapman and Hall, London, pp. 437-481.

Rosen, B.R., Smith, A.B., 1988. Tectonics from fossils? Analysis of reef-coral and sea-urchin distributions from late Cretaceous to recent, using a new method. In: Audley-Charles, M.G., Hallman, A. (Eds.), Gondwana and Tethys, 37. Special Publication of the Geological Society of London, pp. 275-306.

Sarquis, O., Borges-Pereira, J., Mac Cord, J.R., Gomes, T.F., Cabello, P.H., Lima, M.M., 2004. Epidemiology of Chagas disease in Jaguaruana, Ceará, Brazil. I. Presence of triatomines and index of Trypanosoma cruzi infection in four localities of a rural area. Mem. Inst. Oswaldo Cruz 99, 263-270.

Sarquis, O., Sposina, R., de Oliveira, T.G., Mac Cord, J.R., Cabello, P.H., Borges-Pereira, J., Lima, M.M., 2006. Aspects of peridomiciliary ecotopes in rural areas of Northeastern Brazil associated to triatomine (Hemiptera, Reduviidae) infestation, vectors of Chagas disease. Mem. Inst. Oswaldo Cruz 101, 143-147.

Schachter-Broide, J., Dujardin, J.P., Kitron, U., Gürtler, R.E., 2004. Spatial structuring of Triatoma infestans (Hemiptera, Reduviidae) populations from northwestern Argentina using wing geometric morphometry. J. Med. Entomol. 41, 643-649.

Schofield, C.J., Jannin, J., Salvatella, R., 2006. The future of Chagas disease control. Trends Parasitol. 22, 583-588.

Silva, R.A., Bonifácio, P.R., Wanderley, D.M.V., 1999. Doença de Chagas no estado de São Paulo: comparação entre pesquisa ativa de triatomíneos em domicílios e notificação de sua presença pela população em área sob vigilância entomológica. Rev. Soc. Bras. Med. Trop. 32, 653-659.

Silveira, A.C., Feitosa, V.R., Borges, R., 1984. Distribuição de triatomíneos capturados no ambiente domiciliar, no período de 1975/83, Brasil. Rev. Bras. Malariol. Doenças Trop. 39, 15-312.

Siqueira, A.F., 1960. Estudos sobre a reação de precipitina aplicada à identificação de sangue ingerido por triatomíneos. Rev. Inst. Med. Trop. São Paulo 2, 41-53.

TNC (The Nature Conservancy) 2001. Latin America and the Caribbean-vegetation and elevation. http://conserveonline.org/docs/2001/06/lac_veg.jpg.

Teixeira, A.R.L., Monteiro, P.S., Rebelo, J.M., Argañaraz, E.R., Vieira, D., Lauria-Pires, L., Nascimento, R., Vexenat, C.A., Silva, A.R., Ault, S.K., Costa, J.M., 2001. Emerging Chagas disease: trophic network and cycle of transmission of Trypanosoma cruzi from palm trees in the Amazon. Emerg. Infect. Dis. 7, 100-112.

Valente, V.C., Valente, S.A.S., Carcavallo, R.U., Rocha, D.S., Galvão, C., Jurberg, J., 2001 Considerações sobre uma nova espécie do gênero Rhodnius Stål, do estado do Pará, Brasil (Hemiptera, Reduviidae, Triatominae). Entomol. Vect. 8, 65-80.

Villegas, J., Feliciangeli, M.D., Dujardin, J.P., 2002. Wing shape divergence between Rhodnius prolixus from Cojedes (Venezuela) and Rhodnius robustus from Mérida (Venezuela). Infect. Genet. Evol. 2, 121-128.

WHO (World Health Organisation) 2004. The World Health Report 2004: Changing History. World Health Organisation, Geneva, xvii + 170 pp.

World Bank, 1993. World Development Report 1993. Investing in Health. Oxford University Press, New York, NY, 329 pp.

WWF-TNC (World Wildlife Fund and The Nature Conservancy) 2001. Ecoregions of Latin America and the Caribbean. http://conserveonline.org/docs/ 2001/06/lac_ecoregions.jpg.

Zeledón, R., Marín, F., Calvo, N., Lugo, E., Valle, S., 2006. Distribution and ecological aspects of Rhodnius pallescens in Costa Rica and Nicaragua and their epidemiological implications. Mem. Inst. Oswaldo Cruz 101, 75-79. 